\title{
Measuring and modelling the isotopic composition of soil respiration: insights from a grassland tracer experiment
}

\author{
U. Gamnitzer ${ }^{1}$, A. B. Moyes ${ }^{2, *}$, D. R. Bowling ${ }^{2}$, and H. Schnyder ${ }^{1}$ \\ ${ }^{1}$ Lehrstuhl für Grünlandlehre, Technische Universität München, Alte Akademie 12, 85350 Freising-Weihenstephan, Germany \\ ${ }^{2}$ Dept. of Biology, University of Utah, 257 South 1400 East, Salt Lake City, UT 84112, USA \\ *now at: School of Natural Sciences, University of California, Merced, 5200 North Lake Road, Merced, CA 95343, USA
}

Received: 26 November 2010 - Published in Biogeosciences Discuss.: 5 January 2011

Revised: 17 May 2011 - Accepted: 18 May 2011 - Published: 26 May 2011

\begin{abstract}
The carbon isotopic composition $\left(\delta^{13} \mathrm{C}\right)$ of $\mathrm{CO}_{2}$ efflux $\left(\delta^{13} \mathrm{C}_{\text {efflux }}\right.$ ) from soil is generally interpreted to represent the actual isotopic composition of the respiratory source $\left(\delta^{13} \mathrm{C}_{\mathrm{Rs}}\right)$. However, soils contain a large $\mathrm{CO}_{2}$ pool in airfilled pores. This pool receives $\mathrm{CO}_{2}$ from belowground respiration and exchanges $\mathrm{CO}_{2}$ with the atmosphere (via diffusion and advection) and the soil liquid phase (via dissolution). Natural or artificial modification of $\delta^{13} \mathrm{C}$ of atmospheric $\mathrm{CO}_{2}$ $\left(\delta^{13} \mathrm{C}_{\mathrm{atm}}\right)$ or $\delta^{13} \mathrm{C}_{\mathrm{Rs}}$ causes isotopic disequilibria in the soilatmosphere system. Such disequilibria generate divergence of $\delta^{13} \mathrm{C}_{\text {efflux }}$ from $\delta^{13} \mathrm{C}_{\mathrm{Rs}}$ (termed "disequilibrium effect").

Here, we use a soil $\mathrm{CO}_{2}$ transport model and data from a ${ }^{13} \mathrm{CO}_{2} /{ }^{12} \mathrm{CO}_{2}$ tracer experiment to quantify the disequilibrium between $\delta^{13} \mathrm{C}_{\text {efflux }}$ and $\delta^{13} \mathrm{C}_{\mathrm{Rs}}$ in ecosystem respiration. The model accounted for diffusion of $\mathrm{CO}_{2}$ in soil air, advection of soil air, dissolution of $\mathrm{CO}_{2}$ in soil water, and belowground and aboveground respiration of both ${ }^{12} \mathrm{CO}_{2}$ and ${ }^{13} \mathrm{CO}_{2}$ isotopologues. The tracer data were obtained in a grassland ecosystem exposed to a $\delta^{13} \mathrm{C}_{\mathrm{atm}}$ of $-46.9 \%$ o during daytime for 2 weeks. Nighttime $\delta^{13} \mathrm{C}_{\mathrm{efflux}}$ from the ecosystem was estimated with three independent methods: a laboratory-based cuvette system, in-situ steady-state open chambers, and in-situ closed chambers.

Earlier work has shown that the $\delta^{13} \mathrm{C}_{\text {efflux }}$ measurements of the laboratory-based and steady-state systems were consistent, and likely reflected $\delta^{13} \mathrm{C}_{\mathrm{Rs}}$. Conversely, the $\delta^{13} \mathrm{C}_{\text {efflux }}$ measured using the closed chamber technique differed from these by $-11.2 \%$. Most of this disequilibrium effect $(9.5 \%$ ) was predicted by the $\mathrm{CO}_{2}$ transport model. Isotopic disequilibria in the soil-chamber system were introduced by changing $\delta^{13} \mathrm{C}_{\mathrm{atm}}$ in the chamber headspace at the onset of the
\end{abstract}

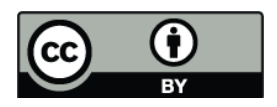

Correspondence to: U. Gamnitzer (ulrike.gamnitzer@wzw.tum.de) measurements. When dissolution was excluded, the simulated disequilibrium effect was only $3.6 \%$. Dissolution delayed the isotopic equilibration between soil $\mathrm{CO}_{2}$ and the atmosphere, as the storage capacity for labelled $\mathrm{CO}_{2}$ in waterfilled soil pores was 18 times that of soil air.

These mechanisms are potentially relevant for many studies of $\delta^{13} \mathrm{C}_{\mathrm{Rs}}$ in soils and ecosystems, including FACE experiments and chamber studies in natural conditions. Isotopic disequilibria in the soil-atmosphere system may result from temporal variation in $\delta^{13} \mathrm{C}_{\mathrm{Rs}}$ or diurnal changes in the mole fraction and $\delta^{13} \mathrm{C}$ of atmospheric $\mathrm{CO}_{2}$. Dissolution effects are most important under alkaline conditions.

\section{Introduction}

The carbon isotopic composition $\left(\delta^{13} \mathrm{C}\right)$ of soil respiration is often interpreted in terms of environmental and metabolic effects on soil carbon dynamics (e.g., McDowell et al., 2004; Ekblad et al., 2005; Mortazavi et al., 2005; Bahn et al., 2009; Gavrichkova et al., 2011; Salmon et al., 2011; Werner and Gessler, 2011). In general, $\delta^{13} \mathrm{C}$ of the respiratory source $\left(\delta^{13} \mathrm{C}_{\mathrm{Rs}}\right)$ is not measured directly, but is equated with $\delta^{13} \mathrm{C}$ of $\mathrm{CO}_{2}$ efflux $\left(\delta^{13} \mathrm{C}_{\mathrm{efflux}}\right)$. However, soil $\mathrm{CO}_{2}$ efflux can differ isotopically from concurrent respiratory $\mathrm{CO}_{2}$ production due to transient conditions within the soil $\mathrm{CO}_{2}$ pool. This divergence (termed "disequilibrium effect" in the following) complicates the interpretation of $\delta^{13} \mathrm{C}_{\mathrm{Rs}}$. Here we investigate mechanisms affecting this disequilibrium effect.

Transient conditions in the soil diffusive system have been observed under natural conditions (e.g., Dudziak and Halas, 1996; Millard et al., 2008; Maseyk et al., 2009; Moyes et al., 2010), but may be particularly evident following tracer application. For instance, Staddon et al. (2003) and Leake et al.

Published by Copernicus Publications on behalf of the European Geosciences Union. 
(2006) noted a diffusion of $\mathrm{CO}_{2}$ tracer into the soil during pulse-labelling experiments and mentioned this as a potential source of error for estimates of $\delta^{13} \mathrm{C}_{\mathrm{Rs}}$. Indeed, Subke et al. (2009) used a diffusion model to show that ${ }^{13} \mathrm{CO}_{2}$ pulselabelling of atmospheric $\mathrm{CO}_{2}$ led to a change in the $\delta^{13} \mathrm{C}$ of $\mathrm{CO}_{2}$ in soil pores, due to transfer of the tracer into the soil pore space. Back-diffusion of the tracer into the atmosphere after labelling was thought to cause an abiotic tracer flux (non-biological tracer flux from the soil into the overlying atmosphere, due to physical processes rather than to respiration of previously assimilated labelled carbon) for up to $2 \mathrm{~d}$ after tracer application. Recently, Ohlsson (2011) investigated $\delta^{13} \mathrm{C}_{\text {efflux }}$ in the dataset of Subke et al. with a diffusion model, which was designed to simulate pulse labelling experiments. To our knowledge, this is the only study quantifying the effects of tracer application and associated changes in $\delta^{13} \mathrm{C}$ in soil pore $\mathrm{CO}_{2}$ on $\delta^{13} \mathrm{C}_{\text {efflux }}$ in a mechanistic way.

In addition to the soil air pores, Högberg et al. (2008) suggested that isotopically labelled $\mathrm{CO}_{2}$ would also dissolve in soil water. The amount of $\mathrm{CO}_{2}$ dissolved in water (more precisely the sum of dissolved $\mathrm{CO}_{2}$, carbonic acid, bicarbonate and carbonate) can be several times higher than the amount of $\mathrm{CO}_{2}$ in the same volume of air. Thus, transient conditions in dissolved $\mathrm{CO}_{2}$ will likely increase the abiotic tracer flux compared to conditions where dissolution in water is not important, as predicted by Ohlsson (2011). The extent of the contribution from the dissolved $\mathrm{CO}_{2}$ storage pool depends on the equilibration time between $\mathrm{CO}_{2}$ in the gaseous and dissolved phase: when this equilibration occurs quickly compared to the residence time of $\mathrm{CO}_{2}$ in soil air pores, then the total soil $\mathrm{CO}_{2}$ pool (gaseous+dissolved $\mathrm{CO}_{2}$ ) is expected to influence $\delta^{13} \mathrm{C}_{\text {efflux }}$ by prolonging the disequilibrium. Despite the potential of dissolution to affect $\delta^{13} \mathrm{C}_{\text {efflux }}$, a quantitative investigation of this effect is limited to a single study (Ohlsson, 2011).

Another mechanism influencing soil $\mathrm{CO}_{2}$ efflux is advective transport by bulk fluid flow (rather than diffusion). Camarda et al. (2007) and Kayler et al. (2010b) investigated $\delta^{13} \mathrm{C}$ of $\mathrm{CO}_{2}$ in soil air pores and $\delta^{13} \mathrm{C}_{\mathrm{efflux}}$ in advectivediffusive regimes. Bowling et al. (2009) illustrated that the $\delta^{13} \mathrm{C}$ in $\mathrm{CO}_{2}$ within a snowpack depends on the physical nature of the transport mechanism, an analogous dependency may occur for $\mathrm{CO}_{2}$ in soil pores. Advection is also expected to transfer an atmospheric tracer signal into soil air. Advective transport has been described to occur due to chamber artifacts (e.g., Kanemasu et al., 1974; Fang and Moncrieff, 1998; Lund et al., 1999; Davidson et al., 2002; Pumpanen et al., 2004). Even small pressure differences between the inside and outside of chambers, in the order of $1 \mathrm{~Pa}$, have been shown to considerably influence the soil $\mathrm{CO}_{2}$ efflux (Fang and Moncrieff, 1998; Lund et al., 1999). Phillips et al. (2010) found indications that advection introduced by sampling affected estimations of $\delta^{13} \mathrm{C}_{\mathrm{Rs}}$.

Disequilibrium effects can occur in all systems where the diffusive flux profile varies over time. For example, iso- topic disequilibrium can be caused by introduction of an isotopic tracer via ${ }^{13} \mathrm{CO}_{2}$ (Ostle et al., 2000; Carbone and Trumbore, 2007; Högberg et al., 2008; Subke et al., 2009) or ${ }^{14} \mathrm{CO}_{2}$ (Horwath et al., 1994; Carbone et al., 2007) pulse labelling, or in Free-Air $\mathrm{CO}_{2}$ Enrichment (FACE and webFACE) experiments (e.g., Nitschelm et al., 1997; Matamala et al., 2003; Asshoff et al., 2006; Keel et al., 2006; Pregitzer et al., 2006; Taneva et al., 2006). Epron et al. (2011) used a crown chamber for ${ }^{13} \mathrm{CO}_{2}$ labelling of trees to prevent tracer diffusion into soil pores. Similarly, changes in chamber headspace $\mathrm{CO}_{2}$ due to flushing with $\mathrm{CO}_{2}$-free air can affect the measurement of $\delta^{13} \mathrm{C}_{\text {efflux }}$ (Ohlsson et al., 2005). Transient conditions in diffusive flux profiles in the soil of natural (unlabelled) systems can be caused by time-varying respiratory $\mathrm{CO}_{2}$ production (Moyes et al., 2010). Some complications in the interpretation of diffusive flux profiles were discussed by Koehler et al. (2010). From a diffusion experiment involving artificial soil and $\mathrm{CO}_{2}$ source, Kayler et al. (2008) concluded that non-steady-state effects must be considered in field investigations of $\delta^{13} \mathrm{C}_{\mathrm{Rs}}$ in soils. Furthermore, Kayler et al. (2010b) demonstrated in a field study the interrelation between perturbations of $\mathrm{CO}_{2}$ in soil pores and aboveground measurement techniques for $\delta^{13} \mathrm{C}$ of soil respiration. Numerical approaches considering diffusion of $\mathrm{CO}_{2}$ in soil air have been applied to simulate the impact of transient changes in environmental variables (Nickerson and Risk, 2009a; Moyes et al., 2010) or the deployment of respiration chambers (Nickerson and Risk, 2009b,c; Ohlsson, 2010) on $\delta^{13} \mathrm{C}_{\text {efflux }}$ and, again, the disequilibrium effect. For example, $\mathrm{CO}_{2}$ accumulating in the headspace of closed chambers and associated chamber-soil feedbacks can cause deviation of Keeling plots (Keeling, 1958) from linearity (Nickerson and Risk, 2009b; Kammer et al., 2011). For various soil respiration chambers, Nickerson and Risk (2009c) predicted disequilibrium effects mostly ranging around several permil, with a maximum of $15 \%$. The return to equilibrium takes longer if $\mathrm{CO}_{2}$ in soil air pores exchanges with $\mathrm{CO}_{2}$ dissolved in soil water. Accordingly, for a given sampling scheme with fixed sampling times (e.g. Keeling plots), the system deviates stronger from equilibrium when dissolved $\mathrm{CO}_{2}$ is involved in soil gas transport. Thus, the divergence of $\delta^{13} \mathrm{C}_{\mathrm{efflux}}$ from $\delta^{13} \mathrm{C}_{\mathrm{Rs}}$ captured by sampling is expected to be even larger than predicted by Nickerson and Risk.

Soil respiration accounts for a major fraction of grassland ecosystem respiration, thus disequilibrium effects in soils can generally affect the interpretation of the isotopic signal of grassland ecosystem respiration. Shoot respiration (the remaining fraction of ecosystem respiration) is not expected to produce comparable disequilibrium effects for carbon isotopes, since the relatively small $\mathrm{CO}_{2}$ pool in leaf intercellular space is turned over much faster than the soil $\mathrm{CO}_{2}$ pool.

Here, we investigate the disequilibrium effect in ecosystem respiration in a field labelling experiment. In that experiment, a grassland ecosystem was exposed during daytime 
to $\mathrm{CO}_{2}$ with a $\delta^{13} \mathrm{C}$ of $-46.9 \%$ for 2 weeks (Gamnitzer et al., 2009). Nocturnal $\delta^{13} \mathrm{C}_{\mathrm{efflux}}$ of the ecosystem was measured with three independent methods: steady-state open chambers, closed chambers (both in-situ in the field), and laboratory-based cuvettes with excised soil + vegetation blocks. The $\delta^{13} \mathrm{C}_{\mathrm{efflux}}$ data of the open chamber measurements agreed with those of the cuvette measurements (Gamnitzer et al., 2009). This indicated that the $\delta^{13} \mathrm{C}_{\mathrm{efflux}}$ of the open chamber measurements gave an accurate estimate of $\delta^{13} \mathrm{C}_{\mathrm{Rs}}$. In consequence, we used the open chamber data as "true" $\delta^{13} \mathrm{C}_{\mathrm{Rs}}$ in the following.

The closed chamber measurements employed a Keeling plot approach. These estimates of ecosystem $\delta^{13} \mathrm{C}_{\text {efflux }}$ deviated by $\sim 10 \%$ ofrom $\delta^{13} \mathrm{C}_{\mathrm{Rs}}$. We suspected that this discrepancy was associated with a disequilibrium effect. Thus, the aim of the present work is to quantify the impact of mechanisms which could underlie such a disequilibrium effect between $\delta^{13} \mathrm{C}_{\mathrm{Rs}}$ and $\delta^{13} \mathrm{C}_{\text {efflux }}$. In particular, we investigated effects of diffusion of $\mathrm{CO}_{2}$ in soil gas, dissolution of $\mathrm{CO}_{2}$ in soil water, and advection of soil gas due to chamber pressurization during labelling. For this purpose, we present a new soil $\mathrm{CO}_{2}$ transport model which accounts for respiratory $\mathrm{CO}_{2}$ production, diffusion, dissolution, and advection of both ${ }^{12} \mathrm{CO}_{2}$ and ${ }^{13} \mathrm{CO}_{2}$. We applied the soil $\mathrm{CO}_{2}$ transport model to evaluate the mechanism(s) underlying abioticallydriven flux of tracer. We simulated the labelling experiment and predicted Keeling plot intercepts for nocturnal $\mathrm{CO}_{2}$ accumulation in the closed chambers with the model. Simulation results were compared to observations to assess the quantitative importance of the different mechanisms underlying the disequilibrium effect. Lastly, we discuss the consequences of these mechanisms for commonly used isotopic approaches for the study of soil and ecosystem respiration.

\section{Materials and methods}

\subsection{Soil $\mathrm{CO}_{2}$ transport model}

The transport of $\mathrm{CO}_{2}$ in soil pore spaces and exchange with the overlying atmosphere was simulated using a vertical (one-dimensional) soil $\mathrm{CO}_{2}$ transport model, which also included an aboveground (shoot) respiration component. Isotopologues of $\mathrm{CO}_{2}$ were treated as separate gases using a separate set of equations for each. The total $\mathrm{CO}_{2}$ concentration $\left({ }^{12} \mathrm{CO}_{2}+{ }^{13} \mathrm{CO}_{2}\right)$ and the $\delta^{13} \mathrm{C}$ of $\mathrm{CO}_{2}\left(\delta^{13} \mathrm{C}=\right.$ $R_{\text {sample }} / R_{\text {standard }}-1$, where $R_{\text {sample }}$ and $R_{\text {standard }}$ are the ${ }^{13} \mathrm{C} /{ }^{12} \mathrm{C}$ ratios in the sample and in the international VPDB standard) were calculated from modelled ${ }^{12} \mathrm{CO}_{2}$ and ${ }^{13} \mathrm{CO}_{2}$. The model was based on the following mass balance equation (Šimůnek and Suarez, 1993; Fang and Moncrieff, 1999):

$\frac{\partial c_{\mathrm{T}}}{\partial t}=-\frac{\partial}{\partial z}\left(J_{\mathrm{diff}}+J_{\mathrm{adv}}\right)+P_{\mathrm{Rs}}$.

$J_{\text {diff }}$ and $J_{\text {adv }}$ describe the $\mathrm{CO}_{2}$ fluxes $\left(\mu \mathrm{mol} \mathrm{m} \mathrm{m}^{-2} \mathrm{~s}^{-1}\right)$ caused by diffusion in the gas phase and by advection of soil air, respectively. $P_{\mathrm{Rs}}$ represents the total $\mathrm{CO}_{2}$ production $\left(\mu \mathrm{mol} \mathrm{m}{ }^{-3} \mathrm{~s}^{-1}\right.$ ) by the respiratory source, including belowground and aboveground respiration. $t$ denotes the time (s) and $z$ the depth $(\mathrm{m})$ below the soil surface. $c_{\mathrm{T}}$ is the total $\mathrm{CO}_{2}$ concentration (molar concentration; $\mu \mathrm{mol} \mathrm{m}{ }^{-3}$ ) in both the gas and liquid phases and is given by

$c_{\mathrm{T}}=c_{\mathrm{a}} \varepsilon_{\mathrm{a}}+c_{\mathrm{w}} \varepsilon_{\mathrm{w}}$,

where $c_{\mathrm{a}}$ and $c_{\mathrm{w}}$ are the $\mathrm{CO}_{2}$ concentrations $\left(\mu \mathrm{molm} \mathrm{m}^{-3}\right)$ in the gas and dissolved phase. Conversion between $\mathrm{CO}_{2}$ concentration $c_{\mathrm{a}}\left(\mu \mathrm{mol} \mathrm{m}{ }^{-3}\right)$ and $\mathrm{CO}_{2}$ mole fraction $C$ $\left(\mu \mathrm{mol} \mathrm{mol}^{-1}\right.$ ) followed $c_{\mathrm{a}}=C / V_{\mathrm{mol}}$, where $V_{\text {mol }}$ is the molar volume of an ideal gas $\left(22.4 \mathrm{~L} \mathrm{~mol}^{-1}\right.$ at standard conditions; adapted to site conditions for temperature and pressure). $\varepsilon_{\mathrm{a}}$ and $\varepsilon_{\mathrm{w}}$ denoted the volumetric fractions $\left(\mathrm{m}^{3} \mathrm{~m}^{-3}\right)$ of air and water in the soil. The total (air-filled + water-filled) porosity of the soil, $\varepsilon_{\text {tot }}\left(\mathrm{m}^{3} \mathrm{~m}^{-3}\right)$, is given by

$\varepsilon_{\mathrm{tot}}=\varepsilon_{\mathrm{a}}+\varepsilon_{\mathrm{w}}$.

The total amount of carbon in the dissolved phase was calculated according to Wood et al. (1993) as the sum of $\mathrm{H}_{2} \mathrm{CO}_{3}$ (aq) (which summarises $\mathrm{CO}_{2}(\mathrm{aq})$ and $\mathrm{H}_{2} \mathrm{CO}_{3}$, as is commonly used) and $\mathrm{HCO}_{3}^{-}$(bicarbonate). Thus,

$c_{\mathrm{w}}=\left[\mathrm{H}_{2} \mathrm{CO}_{3}(\mathrm{aq})\right]+\left[\mathrm{HCO}_{3}^{-}\right]$,

where the square brackets indicate concentrations. $\mathrm{H}_{2} \mathrm{CO}_{3}$ (aq) and $\mathrm{HCO}_{3}^{-}$represent $99.9 \%$ of the dissolved carbon species in the $\mathrm{pH}$ range at our study site $(\mathrm{pH} \sim 7.5$, see Table 1). Thus, $\mathrm{CO}_{3}^{2-}$ was neglected. The chemical equilibrium reactions and constants can be expressed as (e.g., Stumm and Morgan, 1996)

$\mathrm{CO}_{2}(\mathrm{~g})+\mathrm{H}_{2} \mathrm{O} \rightleftharpoons \mathrm{H}_{2} \mathrm{CO}_{3}(\mathrm{aq}), \quad K_{\mathrm{H}}=\frac{\left[\mathrm{H}_{2} \mathrm{CO}_{3}(\mathrm{aq})\right]}{p_{\mathrm{CO}_{2}}}$,

$\mathrm{H}_{2} \mathrm{CO}_{3}(\mathrm{aq}) \rightleftharpoons \mathrm{H}^{+}+\mathrm{HCO}_{3}^{-}, \quad K_{1}=\frac{\left[\mathrm{H}^{+}\right] \cdot\left[\mathrm{HCO}_{3}^{-}\right]}{\left[\mathrm{H}_{2} \mathrm{CO}_{3}(\mathrm{aq})\right]}$.

These allow the calculation of the concentrations $\left[\mathrm{H}_{2} \mathrm{CO}_{3}(\mathrm{aq})\right]$ and $\left[\mathrm{HCO}_{3}^{-}\right]\left(\mathrm{mol} \mathrm{L}^{-1}\right)$ when $p_{\mathrm{CO}_{2}}$, the $\mathrm{CO}_{2}$ partial pressure $(\mathrm{kPa})$, and the $\mathrm{pH}$ are known. $p_{\mathrm{CO}_{2}}$ was derived from $p_{\mathrm{CO}_{2}}=R T c_{\mathrm{a}}$, where $R$ is the universal gas constant $\left(8.314 \mathrm{~kg} \mathrm{~m}^{2} \mathrm{~s}^{-2} \mathrm{~K}^{-1} \mathrm{~mol}^{-1}\right)$ and $T$ the temperature (K). According to Eqs. (4)-(6), the so-called Bunsen coefficient $B=c_{\mathrm{w}} / c_{\mathrm{a}}$ is given by

$B=K_{\mathrm{H}} R T\left(1+\frac{K_{1}}{\left[\mathrm{H}^{+}\right]}\right)$.

Numerical values for $K_{\mathrm{H}}$, the Henry's law constant, and the equilibrium constant $K_{1}$ were taken from Stumm and Morgan (1996). Fractionation for the dissolution of $\mathrm{CO}_{2}$ in water was included according to Mook et al. (1974) and Vogel et al. (1970), with $\mathrm{H}_{2} \mathrm{CO}_{3}$ (aq) depleted compared to $\mathrm{CO}_{2}(\mathrm{~g})$ by $(-373 / T+0.19) \%$ and $\mathrm{HCO}_{3}^{-}$enriched compared to 
Table 1. Parameters characterizing conditions for $\mathrm{CO}_{2}$ transport in the soil at the Grünschwaige field site.

\begin{tabular}{|c|c|c|}
\hline Parameter & Value (range) & Method of determination \\
\hline $\begin{array}{l}\text { Porosity: } \\
\text { Total } \\
\text { Air-filled }\end{array}$ & $\begin{array}{l}0.57(0.51-0.63) \mathrm{m}^{3} \mathrm{~m}^{-3} \\
0.25(0.20-0.29) \mathrm{m}^{3} \mathrm{~m}^{-3}\end{array}$ & $\begin{array}{l}\text { Estimated from measured wet and dry mass of defined volume of bulk } \\
\text { soil (mean of the top } 10 \mathrm{~cm} \text { of soil layer) and an assumed density of } \\
2.5 \mathrm{~g} \mathrm{~cm}^{-3} \text { for solid matter }\end{array}$ \\
\hline $\begin{array}{l}\text { Respiratory } \mathrm{CO}_{2} \text { source: } \\
\text { Shoot respiration rate } \\
\text { Soil respiration rate } \\
\delta^{13} \mathrm{C}_{\mathrm{Rs}} \text { shoot } \\
\delta^{13} \mathrm{C}_{\mathrm{Rs}} \text { soil }\end{array}$ & $\begin{array}{l}1.7(0.7-2.7) \mu \mathrm{mol} \mathrm{m}^{-2} \mathrm{~s}^{-1} \\
5.0(4.0-6.0) \mu \mathrm{mol} \mathrm{m}^{-2} \mathrm{~s}^{-1} \\
-26.7 \% \text { to }-63.5 \% \text { o } \\
-26.7 \% \text { to }-37.8 \% \text { o }\end{array}$ & $\begin{array}{l}\text { Measurements of nocturnal ecosystem } \mathrm{CO}_{2} \text { efflux (see Sect. 2.3.2) } \\
\text { Gradual change during simulation of labelling experiment (see } \\
\text { Sect. 2.3.2) }\end{array}$ \\
\hline $\begin{array}{l}\text { Partitioning of soil } \\
\text { respiratory source: } \\
\text { Fraction in top } 5 \mathrm{~cm}\end{array}$ & $0.8(0.5-0.9)$ & $\begin{array}{l}\text { Exponential distribution with depth, adapted to root mass distribution } \\
\text { (Klapp, 1971) }\end{array}$ \\
\hline Temperature & $16.5(10-24)^{\circ} \mathrm{C}$ & Observed soil temperature $(5 \mathrm{~cm}$ depth $)$ \\
\hline $\mathrm{pH}$ & $7.5(7.2-7.8)$ & K. Auerswald, unpublished data \\
\hline $\begin{array}{l}\text { Advection: } \\
\text { Darcy velocity }\end{array}$ & $1.1(0.5-5.8) 10^{-5} \mathrm{~m} \mathrm{~s}^{-1}$ & $\begin{array}{l}\text { Determined according to Eq. (11) from observed pressure difference } \\
\text { (Gamnitzer et al., 2009) and assumed air permeability of the soil of } \\
10.1(4.85-52.5) \mu \mathrm{m}^{2} \text { (median and } 25 \%-75 \% \text { quantil; Ball et al., } \\
\text { 1997; Fish and Koppi, 1994; Milne and Haynes, 2004; Munkholm } \\
\text { et al., 2005; Schjønning et al., 2007) }\end{array}$ \\
\hline $\begin{array}{l}\text { Diffusivity model: } \\
D_{\text {soil }} / D_{0}\end{array}$ & $0.030(0.014-0.18)$ & $\begin{array}{l}\text { Millington (1959); Millington and Quirk (1960); Moldrup et al. (1997, } \\
\text { 1999, 2000, 2004) }\end{array}$ \\
\hline
\end{tabular}

$\mathrm{H}_{2} \mathrm{CO}_{3}$ (aq) by $(9866 / T-24.12) \%$, see Mook (2000). This description of dissolution of $\mathrm{CO}_{2}$ in soil water implies instantaneous equilibration between the gaseous and the dissolved phase.

The $\mathrm{CO}_{2}$ fluxes were defined by

$J_{\text {diff }}=-D_{\text {soil }} \frac{\partial c_{\mathrm{a}}}{\partial z}$

$J_{\mathrm{adv}}=v_{\text {Darcy }} c_{\mathrm{a}}$.

$D_{\text {soil }}$ is the diffusion coefficient for $\mathrm{CO}_{2}$ in soil air $\left(\mathrm{m}^{2} \mathrm{~s}^{-1}\right)$, and $v_{\text {Darcy }}$ is the Darcy velocity $\left(\mathrm{m} \mathrm{s}^{-1}\right)$. Equation (8) corresponds to Fick's First Law. $D_{\text {soil }}$ was derived from $D_{0}$, the diffusion coefficient $\left(\mathrm{m}^{2} \mathrm{~s}^{-1}\right)$ for $\mathrm{CO}_{2}$ in air, according to Millington (1959),

$D_{\text {soil }}=D_{0} \frac{\varepsilon_{\mathrm{a}}^{10 / 3}}{\varepsilon_{\mathrm{tot}^{2}}^{2}}$.

$D_{0}$ was derived for the average soil temperature during the field experiment following Fuller et al. (1966) (see also Campbell and Norman, 1998). Further estimates of (effective) soil diffusivity (Millington and Quirk, 1960; Moldrup et al., 1997, 1999, 2000, 2004) were used to investigate sensitivity to the choice of a $D_{\text {soil }}$ model. Fractionation during diffusion was taken into account by applying different diffusivities for the isotopologues (Cerling et al.,
1991): $D_{\text {soil }}\left({ }^{12} \mathrm{CO}_{2}\right) / D_{\text {soil }}\left({ }^{13} \mathrm{CO}_{2}\right)=1.0044$. The Darcy velocity was derived from Darcy's law,

$v_{\text {Darcy }}=\frac{k_{\mathrm{a}}}{\eta_{\mathrm{a}}} \cdot \frac{\Delta p}{\Delta z}$,

where $k_{\mathrm{a}}$ is the air permeability of the soil, $\eta_{\mathrm{a}}$ the dynamic viscosity of air, and $\Delta p$ the pressure difference occuring over the distance $\Delta z$.

For numerical solution of Eq. (1), the soil was divided into $n$ horizontal layers of thickness $\Delta z=L / n$, where $L$ is the total soil depth. An additional top layer (depth 0 ) represented the atmosphere above the soil. The $\mathrm{CO}_{2}$ production by the respiratory source, $P_{\mathrm{Rs}}$, corresponded to belowground (soil) respiration in the soil layers, and to aboveground (shoot) respiration in the top (atmospheric) layer. While the $\mathrm{CO}_{2}$ production rate was set constant with time, the $\delta^{13} \mathrm{C}_{\mathrm{Rs}}$ was adjusted to changing tracer content for simulations of the labelling experiment (see Sect. 2.3.2 below). Gravel below the soil was assumed to exhibit no respiratory $\mathrm{CO}_{2}$ production. Porosity $\left(\varepsilon_{\mathrm{a}}\right.$ and $\left.\varepsilon_{\mathrm{w}}\right)$, temperature and $\mathrm{pH}$ were set constant with time and soil depth. The balance equation (Eq. 1) was combined with Eqs. (2) and (7)-(9), resulting in

$\left(\varepsilon_{\mathrm{a}}+\varepsilon_{\mathrm{W}} B\right) \cdot \frac{\partial c_{\mathrm{a}}}{\partial t}=D_{\text {soil }} \cdot \frac{\partial^{2} c_{\mathrm{a}}}{\partial z^{2}}-v_{\text {Darcy }} \cdot \frac{\partial c_{\mathrm{a}}}{\partial z}+P_{\mathrm{Rs}}$.

For numerical solution, this equation was discretised using time steps $\Delta t$ and depth steps $\Delta z$. This allows one to 
derive the $\mathrm{CO}_{2}$ concentration $c_{\mathrm{a}}(z, t+\Delta t)$ in each layer after a time step $\Delta t$ from the concentrations before the time step $\Delta t$ in that layer $\left(c_{\mathrm{a}}(z, t)\right)$ and in the adjacent layers below $\left(c_{\mathrm{a}}(z+\Delta z, t)\right)$ and above $\left(c_{\mathrm{a}}(z-\Delta z, t)\right)$. In the bottom layer (depth $L$ ), the diffusive exchange occurred only with the layer above. Diffusive exchange with the air pores in the gravel below the soil was neglected, since $\mathrm{CO}_{2}$ concentration in the soil at depth $L$ and in the gravel were identical in the steady-state. Treatment of the top layer depended on the simulated situation, see Sect. 2.3 below.

For model validation, analytical solutions of the mass balance equation (Eq. 1) were generated assuming steady-state conditions (no concentration change with time) and homogenous distribution of respiration with soil depth. For diffusive regimes, the analytical solution was derived according to Cerling (1984). For diffusive-advective regimes, the analytical solution was similar to that of Camarda et al. (2007) and Kayler et al. (2010b), as both groups studied diffusive-advective regimes with a gas reservoir at the bottom of the soil instead of homogeneous production. For $\mathrm{CO}_{2}$ mole fraction, numerical model results agreed within $0.2 \%$ with analytically-derived $\mathrm{CO}_{2}$ mole fraction at all depths. Numerically-derived $\delta^{13} \mathrm{C}$ was within $0.009 \%$ of analytically-derived $\delta^{13} \mathrm{C}$. Furthermore, model estimates perfectly agreed with results presented by Cerling (1984) for the soil parameters given in that study.

\subsection{Field labelling experiment}

The ${ }^{13} \mathrm{CO}_{2} /{ }^{12} \mathrm{CO}_{2}$ field labelling experiment, described in detail by Gamnitzer et al. (2009), was conducted at Grünschwaige Grassland Research Station (Schnyder et al., 2006). The soil at the experimental site was mineral soil (inceptisols), which was used as arable land for more than 40 years before conversion to grassland in 1999 (Schnyder et al., 2006). The temperate grassland ecosystem was continuously labelled for 2 weeks, and ecosystem respiration was measured every night. For this purpose, a chamber system was used, where the chambers were open at their top to the atmosphere ("open-top chambers"), and flushed with air. The label was applied during daytime hours by altering the $\delta^{13} \mathrm{C}$ of $\mathrm{CO}_{2}$ in the chamber headspace air, while $\mathrm{CO}_{2}$ mole fraction was kept similar to ambient. The $\delta^{13} \mathrm{C}$ of the $\mathrm{CO}_{2}$ inside the chamber, to which the plants were exposed during photosynthesis, was $-46.9 \%$.

Each night during the labelling experiment, ecosystem respiration was measured in the field using two different approaches: first, closed chamber measurements were conducted from sunset until approximately midnight; subsequently, open chamber measurements followed for the rest of the night (Fig. 1). For a description of the two respiration measurement approaches in the field see below. The $\mathrm{CO}_{2}$ mole fraction and $\delta^{13} \mathrm{C}$ were analysed in the field with an infrared gas analyser (LI 7000; Li-Cor, Lincoln, NE, USA) and a continuous-flow isotope-ratio mass spectrome- ter (Delta Plus Advantage; Thermo Electron, Bremen, Germany) interfaced with a Gasbench II (providing sample gas separation via a built-in gas chromatograph, and sample and reference gas injection to the mass spectrometer; Thermo Electron, Bremen, Germany) (Schnyder et al., 2004). To ensure synchronous analysis of both quantities for the Keeling plots (see Sect. 2.2.2 below), $\mathrm{CO}_{2}$ mole fraction was substituted by $\mathrm{CO}_{2}$ peak area for the Keeling plots. Schnyder et al. (2004) demonstrated a proportional relationship between $\mathrm{CO}_{2}$ mole fraction and $\mathrm{CO}_{2}$ peak area. Measurement uncertainty of the mass spectrometer (SD of replicate measurements) was $0.09 \%$ for $\delta^{13} \mathrm{C}$, and corresponded to $\sim 2 \mu \mathrm{mol} \mathrm{mol}^{-1}$ for the $\mathrm{CO}_{2}$ peak area.

\subsubsection{Open chamber approach to measure ecosystem respiration}

For the open chamber (more exactly termed steady-state flow-through system, Livingston and Hutchinson, 1995) respiration measurements, the open-top chambers were flushed with air, and $\mathrm{CO}_{2}$ mole fraction and $\delta^{13} \mathrm{C}$ were analysed in air entering and leaving the chamber. Differences between inlet and outlet were attributed to respiratory $\mathrm{CO}_{2}$ production of the ecosystem enclosed in the chamber according to mass balance equations. The total $\mathrm{CO}_{2}$ flux from the ecosystem into the chamber headspace, $F_{\text {efflux }}$, was calculated as

$F_{\text {efflux }}=\frac{F_{\text {air }}}{V_{\text {mol }} A_{\text {chamber }}} \cdot\left(C_{\text {out }}-C_{\text {in }}\right)$,

and the $\delta^{13} \mathrm{C}$ of ecosystem $\mathrm{CO}_{2}$ efflux, $\delta^{13} \mathrm{C}_{\mathrm{efflux}}$, as

$\delta^{13} \mathrm{C}_{\mathrm{efflux}}=\frac{\delta^{13} \mathrm{C}_{\mathrm{out}} \cdot C_{\mathrm{out}}-\delta^{13} \mathrm{C}_{\mathrm{in}} \cdot C_{\mathrm{in}}}{C_{\mathrm{out}}-C_{\mathrm{in}}}$.

$F_{\text {air }}$ is the air flow through the chamber (corresponding to $100 \mathrm{~L} \mathrm{~min}^{-1}$ at standard conditions), $A_{\text {chamber }}$ the chamber base area $\left(0.83 \mathrm{~m}^{2}\right) . C_{\text {in }}$ and $C_{\text {out }}$ are the $\mathrm{CO}_{2}$ mole fractions $\left(\mu \mathrm{mol} \mathrm{mol}{ }^{-1}\right)$ at the chamber inlet and outlet, and $\delta^{13} \mathrm{C}_{\mathrm{in}}$ and $\delta^{13} \mathrm{C}_{\text {out }}$ are the respective $\delta{ }^{13} \mathrm{C}$ values.

\subsubsection{Closed chamber approach to measure ecosystem respiration}

For the closed chamber (more exactly termed non-steadystate non-flow-through system, Livingston and Hutchinson, 1995) respiration measurements, the chamber air supply was disconnected. The chamber was lifted and then placed back in its original position immediately before the beginning of closed chamber measurements. The lifting flushed the labelled air from the chamber headspace and replaced it with ambient air. Thus, the mole fraction and $\delta^{13} \mathrm{C}$ of chamber headspace $\mathrm{CO}_{2}$ at chamber closure in the labelled plots were the same as those in the unlabelled control measurements. The chamber top was then closed with a lid. Subsequently, the $\mathrm{CO}_{2}$ mole fraction and $\delta^{13} \mathrm{C}$ were monitored by analyzing 6 consecutive samples ( 1 sample every 120 s) 


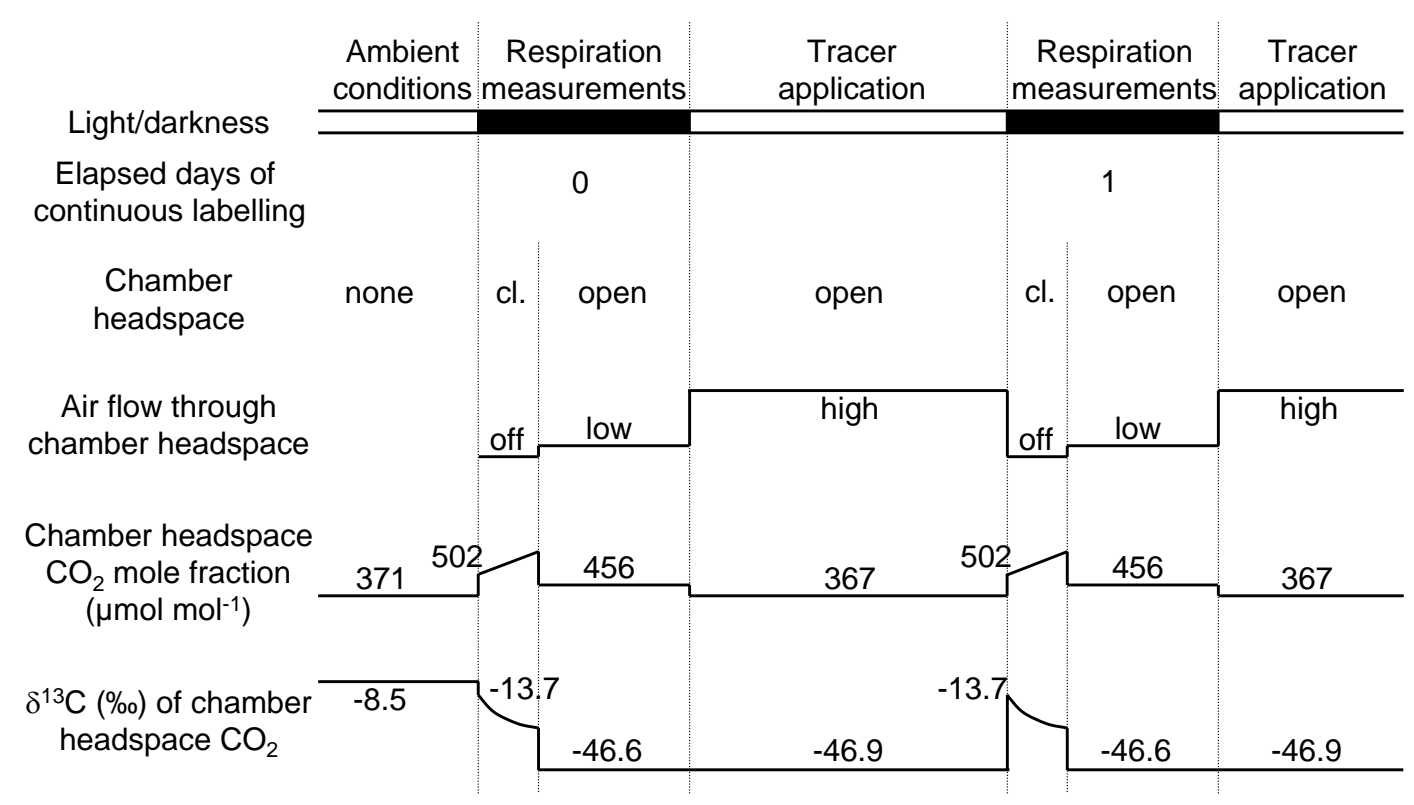

Fig. 1. Schematic sequence of labelling experiment, including chamber headspace conditions (cl.: closed) of air flow, $\mathrm{CO}_{2}$ mole fraction and $\delta^{13} \mathrm{C}$ of $\mathrm{CO}_{2}$. The latter are shown as averages observed during the labelling experiment, and were used as input parameters in the model simulation. For closed chamber headspace, values are given at chamber closure.

within a measurement cycle. Sample air was pumped continuously from the chamber headspace to the analysers at $\sim 1.5 \mathrm{~L} \mathrm{~min}^{-1}$ at standard conditions (corresponding to a turnover time of $7.3 \mathrm{~h}$ for the chamber headspace air). The air removed for sampling was replaced by ambient air entering the chamber through an opening of $1-2 \mathrm{~cm}$ diameter. Assuming advective flow through this opening, the replacement air had the same mole fraction and $\delta^{13} \mathrm{C}_{\text {of }} \mathrm{CO}_{2}$ as the chamber headspace air at chamber closure. It accounted for $\sim 3 \%$ of the total headspace volume of the chamber by the end of a measurement cycle. Thus, replacement air slightly diluted the efflux signal in the chamber headspace.

From the time course of the $\mathrm{CO}_{2}$ increase, $F_{\text {efflux }}$ was calculated as

$F_{\text {efflux }}=\frac{\Delta C}{\Delta t} \cdot \frac{V_{\text {chamber }}}{V_{\text {mol }} A_{\text {chamber }}}$,

where $\Delta C$ is the observed increase in $\mathrm{CO}_{2}$ mole fraction in the chamber headspace during a time interval $\Delta t$, and $V_{\text {chamber }}$ the chamber volume $(660 \mathrm{~L}$, corrected for dilution with ambient air during the measurement cycle). The $\delta^{13} \mathrm{C}_{\text {efflux }}$ was determined with the Keeling plot approach (Keeling, 1958; see Pataki et al., 2003 for applicationn to terrestrial ecosystem research). The 6 samples analysed in the measurement cycle following chamber closure were pooled in one Keeling plot, resulting in an intercept reflecting ecosystem $\delta^{13} \mathrm{C}_{\text {efflux }}$. The Keeling plot intercepts are invariant to the dilution of the efflux signal with background air.

\subsection{Simulation runs}

Model input parameters characterizing conditions for $\mathrm{CO}_{2}$ transport in the soil were determined for the Grünschwaige field site (Table 1). The soil of depth $L=25 \mathrm{~cm}$ was divided into $n=125$ layers of thickness $\Delta z=2 \mathrm{~mm}$. This high depth resolution along with short time steps $\Delta t$, ranging between $1 \mathrm{~s}$ and $12 \mathrm{~s}$, ensured sufficient accuracy of the discrete mass balance approximation and model stability. During daytime labelling, a chamber pressurization of $5 \mathrm{~Pa}$ above ambient was observed due to high daytime air flow (Gamnitzer et al., 2009). This pressurization might have caused vertical (downwards) advection of soil air during daytime labelling. The impacts of this potential chamber artifact and of the dissolution of labelling $\mathrm{CO}_{2}$ in soil water on the disequilibrium effect were investigated independently. For this purpose, model runs were performed including or excluding the individual mechanisms.

\subsubsection{Step changes in $\delta^{13} \mathrm{C}$ of atmospheric $\mathrm{CO}_{2}$}

This simulation investigated the disequilibrium effect that would result from changes in $\delta^{13} \mathrm{C}$ of chamber headspace $\mathrm{CO}_{2}$. In the labelling experiment, such changes occurred at the beginning of the closed chamber measurements, when the labelled air in the chamber headspace was substituted with ambient air. Thus, step changes of $\delta^{13} \mathrm{C}_{\text {of }} \mathrm{CO}_{2}$ in the atmospheric layer $\left(\delta^{13} \mathrm{C}_{\mathrm{atm}}\right)$ from $-8.5 \%$ (ambient conditions, see Fig. 1) to $-46.9 \%$ (labelling conditions, see Fig. 1), and vice versa, were simulated. To exclude disequilibrium effects 
not related to changes in $\delta^{13} \mathrm{C}_{\mathrm{atm}}$, all other parameters (including $\delta^{13} \mathrm{C}_{\mathrm{Rs}}$ ) were kept constant and advection was excluded. Soil $\mathrm{CO}_{2}$ efflux was derived from the simulated $\mathrm{CO}_{2}$ concentration according to Fick's First Law:

$F_{\text {efflux }}(t)=D_{\text {soil }} \cdot \frac{\Delta c_{\mathrm{a}}(t)}{\Delta z}$,

where $\Delta c_{\mathrm{a}}$ is the concentration difference at the soil surface (between the air pores of the uppermost soil layer and the overlying atmosphere). The $\delta^{13} \mathrm{C}_{\text {efflux }}$ was derived from the ratio of the simulated ${ }^{12} \mathrm{CO}_{2}$ and ${ }^{13} \mathrm{CO}_{2}$ effluxes.

\subsubsection{Labelling experiment and chamber-based respiration measurements}

To simulate $\mathrm{CO}_{2}$ mole fraction and $\delta^{13} \mathrm{C}$ during the labelling experiment, boundary conditions for the atmospheric layer were chosen according to the respective chamber mode (Fig. 1). First, the model was run under ambient conditions, keeping $\mathrm{CO}_{2}$ mole fraction and $\delta^{13} \mathrm{C}$ in the atmospheric layer at fixed values $\left(371 \mu \mathrm{mol} \mathrm{mol}^{-1}\right.$ and $-8.5 \%$, see Fig. 1), until soil profiles of $\mathrm{CO}_{2}$ and $\delta^{13} \mathrm{C}$ reached steady-state. Then closed chamber measurements of $\delta^{13} \mathrm{C}_{\text {efflux }}$ of the unlabelled ecosystem (control) were simulated. For closed chamber simulations, soil $\mathrm{CO}_{2}$ efflux and shoot-respired $\mathrm{CO}_{2}$ were mixed with ambient (background) air in the chamber headspace. Analogous to Keeling plot sampling during the field measurements, 6 consecutive values of simulated atmospheric layer $\mathrm{CO}_{2}$ mole fraction and $\delta^{13} \mathrm{C}$ in 2 min intervals were pooled to generate a Keeling plot. Subsequently, conditions during open chamber measurements were simulated by forcing $\mathrm{CO}_{2}$ mole fraction and $\delta^{13} \mathrm{C}$ in the atmospheric layer to be constant for $7 \mathrm{~h}$ (fraction of the dark period not covered by closed chamber simulations). Then, a daytime labelling period of $16 \mathrm{~h}$ followed: the $\mathrm{CO}_{2}$ in the atmospheric layer was kept constant at labelling conditions $\left(367 \mu \mathrm{mol} \mathrm{mol}^{-1}\right.$ and $-46.9 \%$, see Fig. 1 ), and $\delta^{13} \mathrm{C}_{\mathrm{Rs}}$ was adjusted to include a fractional contribution of labelled carbon according to the results of Gamnitzer et al. (2009) (see below for details). The cycle of modelling nighttime measurements in closed and open chambers and daytime labelling was repeated to simulate the 2-week-long continuous labelling experiment.

To account for the increasing amount of label in the respiratory source during the experiment, $\delta^{13} \mathrm{C}_{\mathrm{Rs}}$ was adjusted from day to day according to the "true" time course of tracer. The latter was derived from the fit (Gamnitzer et al., 2009, see also Fig. 2, solid line) to the open chamber data (Fig. 2, open circles). To partition this signal into belowground (soil) and aboveground (shoot) respiratory $\mathrm{CO}_{2}$ production (which are required as model input parameters), three respiratory sources were distinguished. The first, decomposition of soil organic matter, was located in the soil, did not respire any tracer $\left(\delta^{13} \mathrm{C}\right.$ constant at $-26.7 \%$ ) and contributed $52 \%$ of ecosystem respiration (Gamnitzer et al., 2009). The other two sources reflected aboveground and belowground autotrophic respiration, where each was assumed to contribute

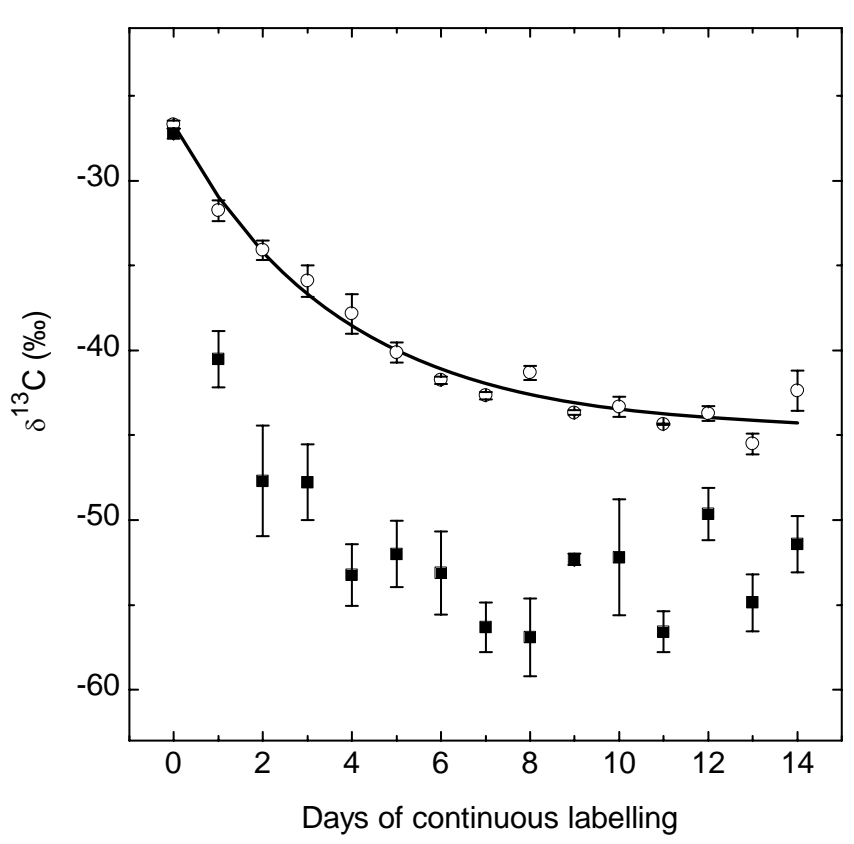

Fig. 2. $\delta^{13} \mathrm{C}$ of nocturnal ecosystem $\mathrm{CO}_{2}$ efflux observed by the open (open circles; Gamnitzer et al., 2009) and closed (black squares) chamber methods during $14 \mathrm{~d}$ of continuous labelling. Error bars: SE of replicate plots, $n=2-10$. The line represents the fit to the open chamber data (Gamnitzer et al., 2009).

$50 \%$ of autotrophic respiration. Both supplied recentlyassimilated carbon from a labelled pool $\left(\delta^{13} \mathrm{C}\right.$ changed from $-26.7 \%$ o to $-64.4 \%$ with a pool half-life of $2.6 \mathrm{~d}$; Gamnitzer et al., 2009). In total, $\delta^{13} \mathrm{C}_{\mathrm{Rs}}$ changed from $-26.7 \%$ to $-37.8 \%$ for the belowground source and from $-26.7 \%$ o to $-63.5 \%$ o for the aboveground source in the simulation of the 14-days-long labelling period. In contrast, soil and shoot respiration rates were kept constant during a simulation run.

\subsubsection{Sensitivity analysis and model assumptions}

To investigate model sensitivity, simulation runs were performed with individual input parameters varying within the ranges given in Table 1. These ranges represent the uncertainty in determination of the input parameters. The partitioning of the autotrophic respiratory source to belowground and aboveground fractions (assumed 50\%:50\%, see above) was allowed to vary between $20 \%: 80 \%$ and $80 \%: 20 \%$. Diffusivity of $\mathrm{CO}_{2}$ in the soil was derived from various models to account for the uncertainty connected with the choice of a $D_{\text {soil }}$ model.

Several assumptions behind the model were chosen according to the specific conditions at this particular field site. The assumption of homogeneous distribution of pore size with depth is based on the past land use of the site as arable land, including periodic tillage. With conversion to grassland 8 years before the labelling experiment, differentiation of pore size distribution could have started. To account for 
this, the uncertainty range includes the observed variation in porosity between the soil surface $(0-3 \mathrm{~cm}$ average) and a depth of $7-10 \mathrm{~cm}$ (Table 1). Similarly, depth variation in $\mathrm{pH}$ is neglected, in particular because the site shows calcareous characteristics with high buffering capacity. Variations of soil $\mathrm{pH}$ in the rhizosphere can be high, but are limited spatially (few millimeters around the growing parts of roots, see e.g. Revsbech et al., 1999) and temporally (within days, see e.g. Flessa and Fischer, 1992). Therefore, they were not considered in the present study.

Disregarding respiratory $\mathrm{CO}_{2}$ production in the gravel below the soil implied that the entire production of the observed $\mathrm{CO}_{2}$ efflux was partitioned to the soil layer. Since this corresponded to a shift in the depth distribution of the respiratory source, sensitivity of the model results to variations in the depth distribution were investigated. Furthermore, a one-dimensional model was used in the present chamber investigation. For the upper half of the soil layer, this simplification was appropriate due to mechanical suppression of lateral exchange by the chamber walls. The chambers were inserted into the soil via a soil collar to a depth of $12 \mathrm{~cm}$, compared to a soil depth of $25 \mathrm{~cm}$. Below the soil collar depth, lateral exchange processes were neglected according to the requirements provided by Nickerson and Risk $(2009 \mathrm{~b}, \mathrm{c})$ on soil diffusivity, air-filled porosity and chamber deployment time. Also the chamber used here was about 10 times larger in diameter than the one studied by Nickerson and Risk, minimizing edge effects. Furthermore, the influence of the atmospheric tracer on $\delta^{13} \mathrm{C}$ in soil pores via gas exchange decreases with soil depth, suggesting that lateral effects were small below soil collar depth.

\section{Results}

\subsection{Experimental tracer time series of nocturnal ecosystem $\mathrm{CO}_{2}$ efflux}

The $\delta^{13} \mathrm{C}_{\text {efflux }}$ time series measured in the open chambers during the 14-day labelling period (Fig. 2, open circles) was taken to reflect that of $\delta^{13} \mathrm{C}_{\mathrm{Rs}}$ (see Introduction). Prior to the start of labelling, measurements of $\delta^{13} \mathrm{C}_{\text {efflux }}$ with the closed chamber method (Fig. 2, black squares) did not differ significantly from those with open chambers. But during labelling, closed chamber $\delta^{13} \mathrm{C}_{\text {efflux }}$ was depleted by $11.2 \%$ on average compared to that of open chamber measurements. Notably, the rate of nocturnal $\mathrm{CO}_{2}$ efflux was the same with both methods: $F_{\text {efflux }}$ averaged $6.8 \pm 0.4 \mu \mathrm{mol} \mathrm{m}{ }^{-2} \mathrm{~s}^{-1}( \pm \mathrm{SE}, n=$ 72 ) in the closed chamber, and $6.7 \pm 0.3 \mu \mathrm{mol} \mathrm{m}^{-2} \mathrm{~s}^{-1}$ in the open chamber ( \pm SE, $n=68$; Gamnitzer et al., 2009).

The SD of the Keeling plot intercepts (parameter of linear fit) was $0.86 \%$ on average for an individual Keeling plot, with $R^{2}=0.989$ and $\mathrm{CO}_{2}$ mole fraction covering a range of $120 \mu \mathrm{mol} \mathrm{mol}{ }^{-1}$. Potential biases due to choice of regression method (ordinary least squares regression vs. geomet- ric mean regression) and mixing model approach (Keeling vs. Miller-Tans) were recently discussed (Pataki et al., 2003; Zobitz et al., 2006; Kayler et al., 2010a). Here, the average deviations were $0.09 \%$ o between regression methods and $0.07 \%$ between mixing models approaches. In contrast, the $\mathrm{SD}$ between Keeling plots in replicate ecosystem plots was $4.4 \%$.

\subsection{Simulation of $\mathrm{CO}_{2}$ in soil air in ambient conditions}

Modelled $\mathrm{CO}_{2}$ mole fraction increased with depth from $371 \mu \mathrm{mol} \mathrm{mol}^{-1}$ in the overlying atmosphere to 6500 $18600 \mu \mathrm{mol} \mathrm{mol}^{-1}$ at the bottom of the soil (Fig. 3a,c). The $\delta^{13} \mathrm{C}$ of $\mathrm{CO}_{2}$ changed continuously from $-8.5 \%$ in the atmospheric layer to values between $-21.6 \%$ and $-22.1 \%$ o at the bottom of the soil (Fig. 3b,d). The $\delta^{13} \mathrm{C}$ profile corresponded to the theoretical mixing line (analogous to that illustrated by Bowling et al. (2009) for $\mathrm{CO}_{2}$ in a snowpack) between atmospheric air $(-8.5 \%$ ) and soil air $(-22.3 \%)$, with the latter $4.4 \%$ enriched (Cerling et al., 1991) relative to $\delta^{13} \mathrm{C}_{\mathrm{Rs}}(-26.7 \%$ ). The gradients of both profiles were large in the top few centimeters of the soil and decreased with depth. Accordingly, the main changes occurred above the soil collar depth of $12 \mathrm{~cm}$.

Sensitivity of modelled profiles to uncertainties in input parameters was smallest for temperature, with changes of soil air $\mathrm{CO}_{2}$ mole fraction within $170 \mu \mathrm{mol} \mathrm{mol}^{-1}$ and changes in $\delta^{13} \mathrm{C}$ within $0.1 \%$. Sensitivity was largest for the depth distribution of $\mathrm{CO}_{2}$ production in the soil: up to a doubling of $\mathrm{CO}_{2}$ mole fraction was predicted if production occurred deeper in the soil. In contrast, $\delta^{13} \mathrm{C}$ varied little (within $0.3 \%$ ). All selected input parameter values provided realistic depth profiles of $\mathrm{CO}_{2}$ mole fraction (e.g., Amundson and Davidson, 1990) and $\delta^{13} \mathrm{C}$ (e.g., Cerling, 1984; Amundson et al., 1998). The amount of $\mathrm{CO}_{2}$ in the dissolved phase was 9.5 to 34 times that in soil air. Conversely, $\mathrm{CO}_{2}$ mole fraction and $\delta^{13} \mathrm{C}$ in soil air were independent of dissolution (data not shown).

\subsection{Simulation of step changes in $\delta^{13} \mathrm{C}_{\text {atm }}$}

First, a step change of $\delta^{13} \mathrm{C}_{\mathrm{atm}}$ from $-8.5 \%$ (ambient conditions) to $-46.9 \%$ (labelling conditions) was studied, with $\delta^{13} \mathrm{C}_{\mathrm{Rs}}$ kept constant at $-26.7 \%$ (Fig. 4a). Immediately following the change of $\delta^{13} \mathrm{C}_{\mathrm{atm}}$, the modelled $\delta^{13} \mathrm{C}_{\mathrm{efflux}}$ became $26.2 \%$ enriched relative to $\delta^{13} \mathrm{C}_{\mathrm{Rs}}$ (Fig. $4 \mathrm{c}$ ). Thereafter, $\delta^{13} \mathrm{C}_{\text {efflux }}$ decreased asymptotically towards $\delta^{13} \mathrm{C}_{\mathrm{Rs}}$. Eventually (within hours to days; see below), the soilatmosphere system reached a new isotopic steady-state. Then, a step change in $\delta^{13} \mathrm{C}_{\mathrm{atm}}$ in the opposite direction caused corresponding changes in the other isotopic direction (Fig. 4b), with an initial shift in $\delta^{13} \mathrm{C}_{\text {efflux }}$ to $26.2 \%$ more depleted values. Again, the system tended to a new steady-state (Fig. 4d). 


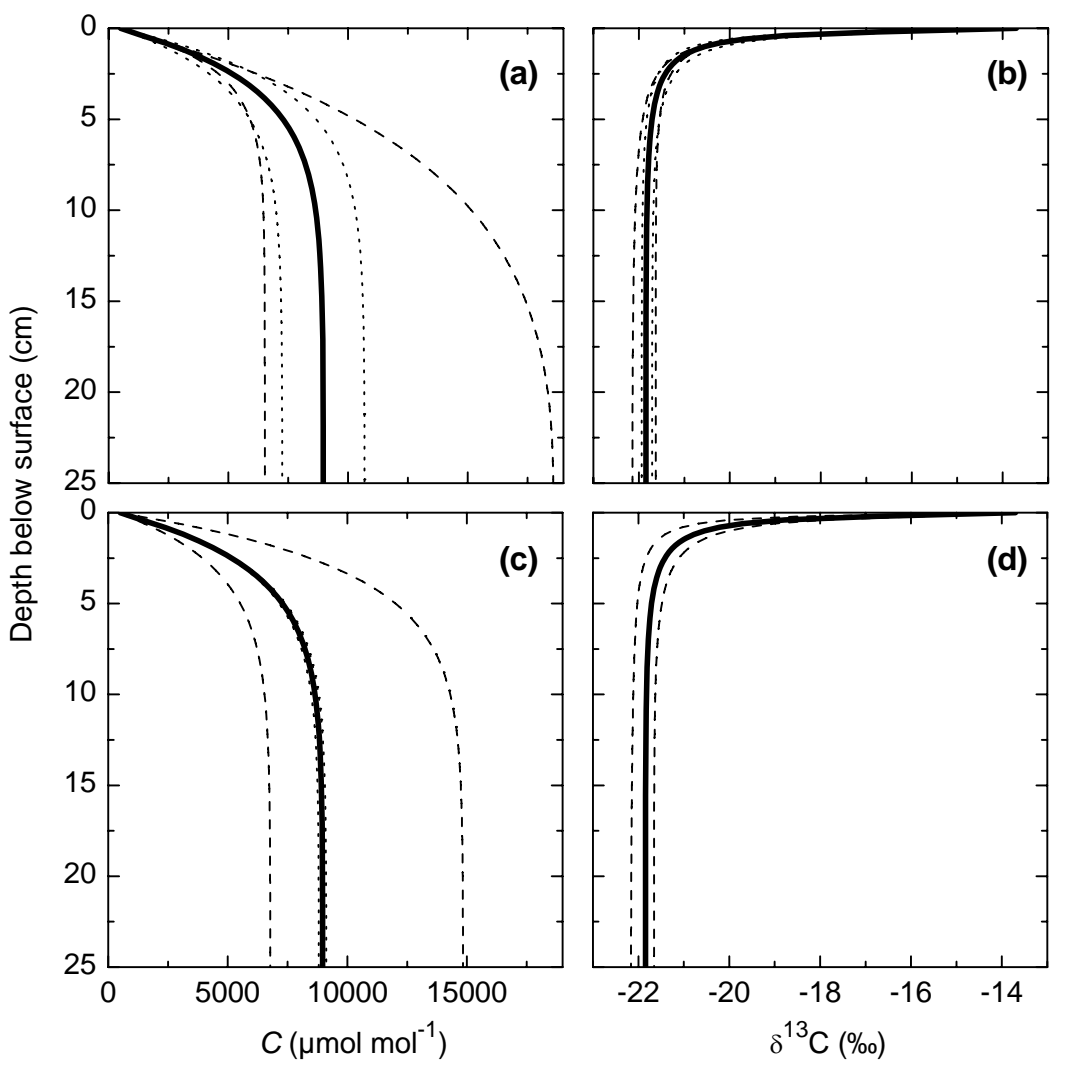

Fig. 3. Modelled depth profiles (thick black lines) of soil $\mathrm{CO}_{2}$ mole fraction $C(\mathbf{a}, \mathbf{c})$ and isotopic composition $\delta^{13} \mathrm{C}(\mathbf{b}$, d) under ambient conditions (the beginning of the labelling experiment) for soil conditions observed at the experimental field site. Sensitivity of each to variations in input parameters within the observed range (Table 1) is indicated by the thin dashed or dotted lines. Upper panels (a, b): depth profiles when depth distribution of $\mathrm{CO}_{2}$ production in soil (dashed) and soil respiration rate (dotted), respectively, were varied. Lower panels (c, d): depth profiles when soil porosity (dashed) and temperature (dotted), respectively, were varied.

These model results were derived from the independent consideration of ${ }^{12} \mathrm{CO}_{2}$ and ${ }^{13} \mathrm{CO}_{2}$ pools and fluxes (Fig. $4 \mathrm{e}-$ 1 ; for clarity, the illustration is limited to the top soil layer). This included the following steps: (1) The change in $\delta^{13} \mathrm{C}_{\mathrm{atm}}$ from ambient to labelling (more ${ }^{13} \mathrm{C}$-depleted) conditions corresponded to an increase of $0.16 \mu \mathrm{mol} \mathrm{mol}^{-1}$ of the atmospheric ${ }^{12} \mathrm{CO}_{2}$ pool and a decrease of $0.16 \mu \mathrm{mol} \mathrm{mol}^{-1}$ of the atmospheric ${ }^{13} \mathrm{CO}_{2}$ pool. (2) These changes of atmospheric $\mathrm{CO}_{2}$ pool sizes caused changes in the differences between soil and atmospheric $\mathrm{CO}_{2}$ pools, which led to a slightly decreased ${ }^{12} \mathrm{CO}_{2}$ and a slightly increased ${ }^{13} \mathrm{CO}_{2}$ diffusive soil efflux (Eq. 16). Note that the changes in the $\mathrm{CO}_{2}$ differences across the soil surface were small $\left(0.16 \mu \mathrm{mol} \mathrm{mol}^{-1}\right)$ compared to the $\mathrm{CO}_{2}$ differences $\left(535 \mu \mathrm{mol} \mathrm{mol}^{-1}\right.$ for ${ }^{12} \mathrm{CO}_{2}$ and $5.9 \mu \mathrm{mol} \mathrm{mol}^{-1}$ for ${ }^{13} \mathrm{CO}_{2}$ ). Nevertheless, these small relative changes in the differences (and thus in the effluxes) of ${ }^{12} \mathrm{CO}_{2}$ and ${ }^{13} \mathrm{CO}_{2}$ resulted in a big shift $(26.2 \%$ ) in $\delta^{13} \mathrm{C}_{\text {efflux }}$. (3) The altered fluxes, in turn, increased the soil pool of ${ }^{12} \mathrm{CO}_{2}$ and decreased that of ${ }^{13} \mathrm{CO}_{2}$. (4) After some time, the system reached a new steady-state with the original fluxes, but with altered ${ }^{12} \mathrm{CO}_{2}$ and ${ }^{13} \mathrm{CO}_{2}$ pool sizes. (5) The switch back to $\delta^{13} \mathrm{C}_{\mathrm{atm}}$ of ambient air again changed the atmospheric $\mathrm{CO}_{2}$ pool sizes, in this case ${ }^{12} \mathrm{CO}_{2}$ was decreased and ${ }^{13} \mathrm{CO}_{2}$ was increased by $0.16 \mu \mathrm{mol} \mathrm{mol}^{-1}$. (6) Accordingly, this led to an increased ${ }^{12} \mathrm{CO}_{2}$ and a decreased ${ }^{13} \mathrm{CO}_{2}$ soil efflux, changing $\delta^{13} \mathrm{C}_{\text {efflux }}$ to a more depleted value. Overall, steps (1) to (6) acted as a tracer flux caused by soil-atmosphere isotopic disequilibria: the $\delta^{13} \mathrm{C}$ of the labelled $\mathrm{CO}_{2}$ was transferred from the atmosphere into the soil (although both the ${ }^{12} \mathrm{CO}_{2}$ and the ${ }^{13} \mathrm{CO}_{2}$ fluxes were directed from the soil to the atmosphere) and vice versa, respectively, via diffusion. It should be noted that during all simulated transitions the ${ }^{12} \mathrm{CO}_{2}$ and ${ }^{13} \mathrm{CO}_{2}$ pool sizes and fluxes changed, while total $\mathrm{CO}_{2}-$ which is the sum of both isotopologues - remained constant.

Dissolution of $\mathrm{CO}_{2}$ in soil water delayed the progression to the new steady-state following a change in $\delta^{13} \mathrm{C}_{\text {atm }}$ (Fig. 5). The $\delta^{13} \mathrm{C}_{\mathrm{efflux}}$ reached $\delta^{13} \mathrm{C}_{\mathrm{Rs}}$ within $0.4 \%$ (corresponding to $1 \%$ of the difference between ambient and labelled $\mathrm{CO}_{2}$ ) after $15.4 \mathrm{~h}$ when dissolution was included in the simulation, and after 49 min (19 times faster) when dissolution was excluded. This relationship of simulated re-equilibration times corresponded to the ratio of total (gaseous + dissolved phase) $\mathrm{CO}_{2}$ to gaseous $\mathrm{CO}_{2}$ in the soil. In contrast, dissolution did 

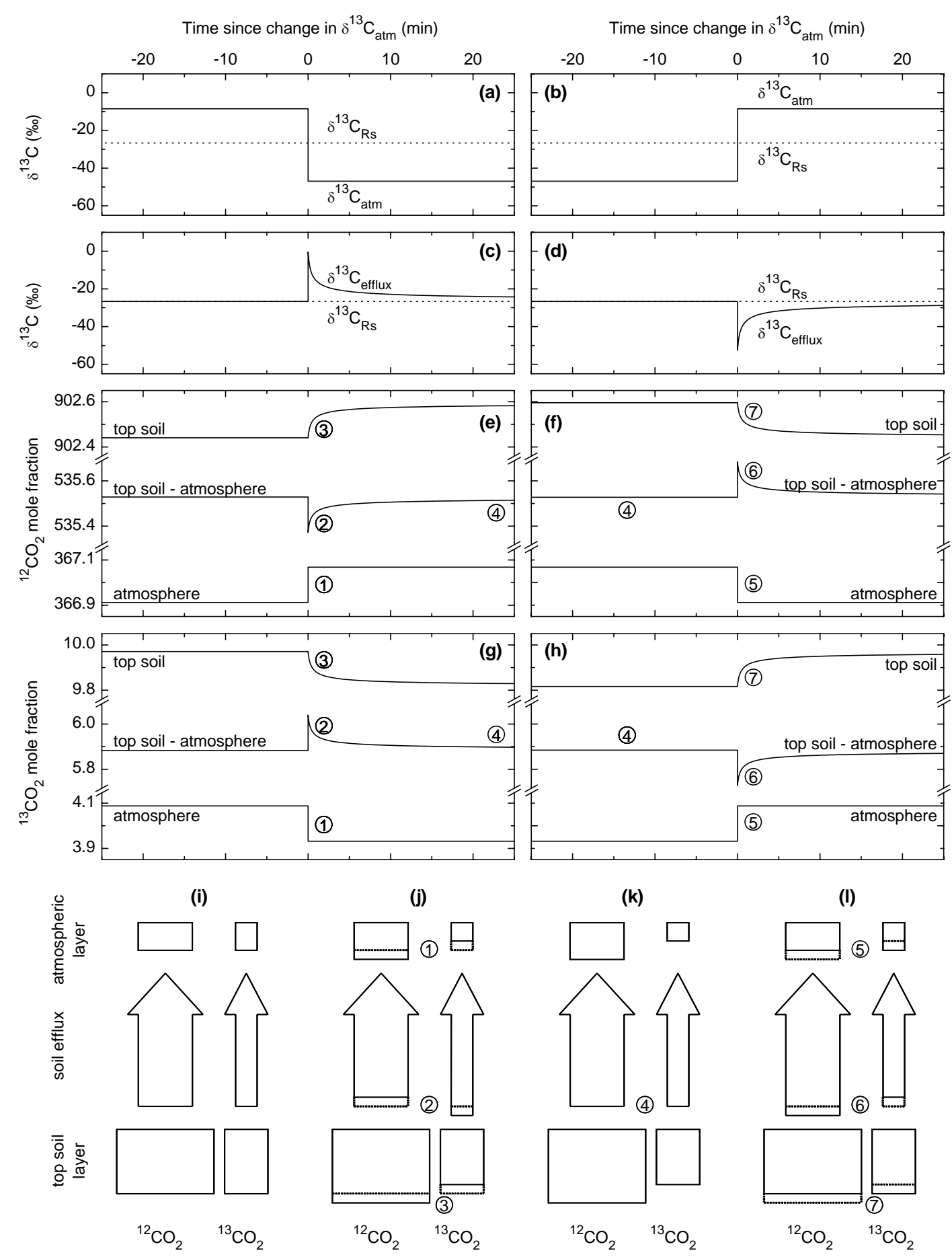

(j)

(k)

(l)
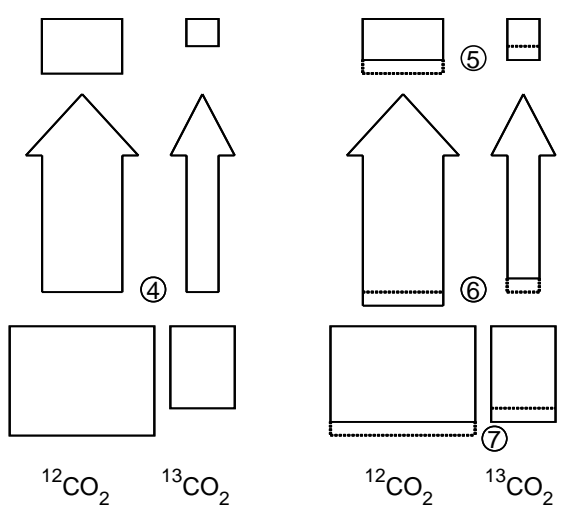

Fig. 4. Conceptual model of the influence of a step change in $\delta^{13} \mathrm{C}_{\mathrm{atm}}$ on $\delta^{13} \mathrm{C}_{\text {efflux }}$. The $\delta^{13} \mathrm{C}_{\mathrm{atm}}$ was switched from ambient (-8.5\%o) to labelling conditions ( $-46.9 \%$ ) (left panels), and vice versa (right panels). (a, b) $\delta^{13} \mathrm{C}_{\mathrm{atm}}$ (solid line) and $\delta^{13} \mathrm{C}_{\mathrm{Rs}}$ (dotted line, constant). (c, d) $\delta^{13} \mathrm{C}_{\mathrm{efflux}}$ (solid line) and $\delta^{13} \mathrm{C}_{\mathrm{Rs}}$ (dotted line, constant). (e, f) ${ }^{12} \mathrm{CO}_{2}$ and (g, h) ${ }^{13} \mathrm{CO}_{2}$ mole fraction in the atmospheric and top soil layer, and the mole fraction difference between these two layers. Bottom (i-l): Schematic illustration of the mechanism underlying abiotic tracer diffusion, treating ${ }^{12} \mathrm{CO}_{2}$ and ${ }^{13} \mathrm{CO}_{2}$ as separate gases. Squares, atmospheric and soil $\mathrm{CO}_{2}$ pools; arrows, $\mathrm{CO}_{2}$ fluxes; dotted lines indicate pools and fluxes prior to the changes; numbered events in the bottom scheme (i-l) match with those in the upper panels (e-h). (i) Unlabelled system in steady-state. (j) Tracer application and associated transitions, namely (1) change in $\delta^{13} \mathrm{C}_{\text {atm }}$ to more depleted value (corresponding to more ${ }^{12} \mathrm{CO}_{2}$ and less ${ }^{13} \mathrm{CO}_{2}$ ), (2) change in $\mathrm{CO}_{2}$ diffusive fluxes due to changes in soil-atmosphere $\mathrm{CO}_{2}$ gradient, and (3) change in soil $\mathrm{CO}_{2}$ pool due to altered fluxes. (k) Labelled system in steady-state with (4) fluxes exhibiting the original $\delta^{13} \mathrm{C}$. (l) $\mathrm{Closed}$ chamber measurement and associated transitions, namely (5) change in $\delta^{13} \mathrm{C}_{\mathrm{atm}}$ to ambient value, (6) change in $\mathrm{CO}_{2}$ diffusive fluxes due to changes in soil-atmosphere $\mathrm{CO}_{2}$ gradient, and (7) change in soil $\mathrm{CO}_{2}$ pool due to altered fluxes. 


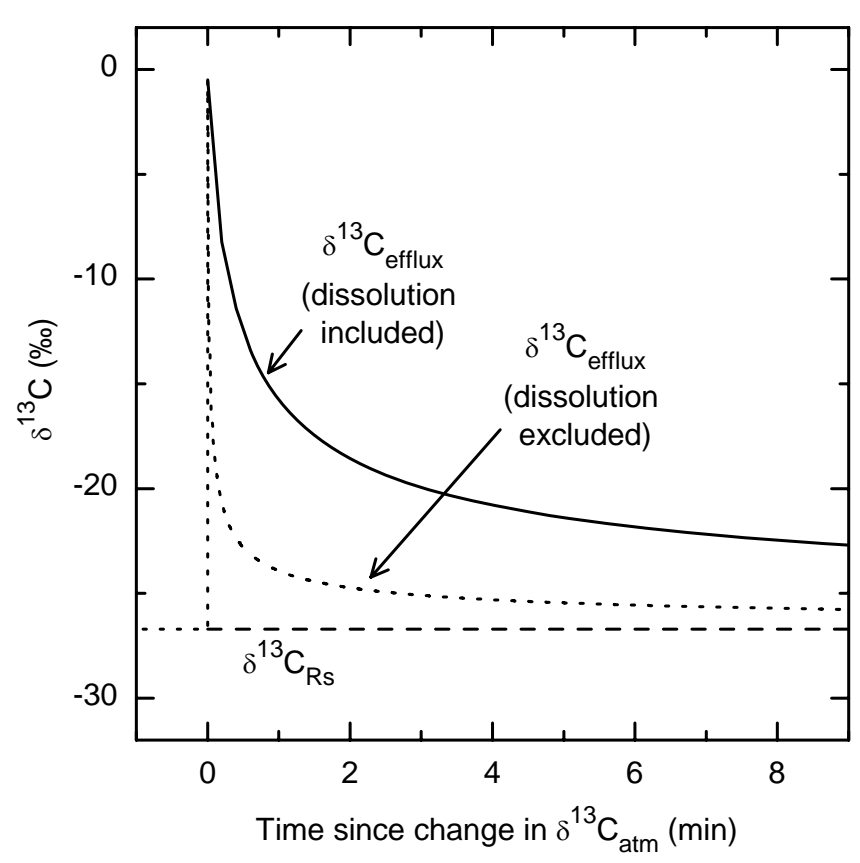

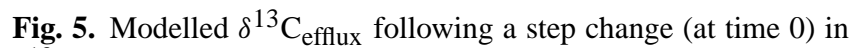
$\delta^{13} \mathrm{C}_{\mathrm{atm}}$ from ambient $(-8.5 \%$ ) to labelling conditions $(-46.9 \%$ o when dissolution of $\mathrm{CO}_{2}$ in soil water was included (solid line, see also Fig. 4c) or excluded in the $\mathrm{CO}_{2}$ transport model (dotted line). $\delta^{13} \mathrm{C}_{\mathrm{Rs}}$ was kept constant at $-26.7 \%$ (dashed line). When lines are overlapping, only the dotted line is shown.

not affect the magnitude of the initial change in soil $\mathrm{CO}_{2}$ efflux. This was driven by the step change in $\delta^{13} \mathrm{C}_{\mathrm{atm}}$ but was independent of the size of the soil $\mathrm{CO}_{2}$ pool.

\subsection{Simulated tracer time series of nocturnal ecosystem $\mathrm{CO}_{2}$ efflux}

Simulated $\delta^{13} C_{\text {efflux }}$ predicted by simulated Keeling plot intercepts (Fig. 6, dashed line) in the labelling experiment was depleted compared to $\delta^{13} \mathrm{C}_{\mathrm{Rs}}$ (Fig. 6, solid line, taken from Fig. 2). When simulations of the closed chamber measurements considered only the diffusion mechanism, then the predicted disequilibrium effect was $1.8 \%$ on average (Fig. 6a). When, in addition, downward advection of soil air during daytime tracer application was included, then the predicted disequilibrium effect increased to $3.6 \%$ (Fig. 6b). When dissolution of $\mathrm{CO}_{2}$ in soil water was included in addition to diffusion, the predicted disequilibrium effect was $4.5 \%$ (Fig. 6c). When diffusion, advection and dissolution were all included in the simulation, the predicted disequilibrium effect was $9.5 \%$ (Fig. 6d). This largely agreed with the observed disequilibrium effect of $11.2 \%$ (Fig. 6, black squares; taken from Fig. 2). Sensitivity analysis (Fig. 7) shows that, within the uncertainties in model input parameters, simulations excluding dissolution did not reproduce the magnitude of the observed disequilibrium effect.
The magnitude of the disequilibrium effect resulting from Keeling plot non-linearity was derived from simulations where $\delta^{13} \mathrm{C}_{\text {atm }}$ remained unchanged and advection was excluded. These conditions were met when Keeling plots were derived before the onset of labelling (see also Fig. 1). These Keeling plots yielded disequilibrium effects smaller than $0.05 \%$.

\section{Discussion}

\subsection{The mechanism underlying the ${ }^{13} \mathrm{C} /{ }^{12} \mathrm{C}$ disequilib- rium between nocturnal ecosystem $\mathrm{CO}_{2}$ efflux and ecosystem respiration}

This work demonstrated that isotopic disequilibria in the soil $\mathrm{CO}_{2}$ pool can explain the divergence between nocturnal ecosystem $\delta^{13} \mathrm{C}_{\mathrm{efflux}}$ and ecosystem $\delta^{13} \mathrm{C}_{\mathrm{Rs}}$ which was observed in a grassland tracer experiment. This ${ }^{13} \mathrm{CO}_{2} /{ }^{12} \mathrm{CO}_{2}$ flux disequilibrium appeared as a transient feature in closed chamber studies (in which the Keeling plot approach was used). A change of $\delta^{13} \mathrm{C}_{\mathrm{atm}}$ at the beginning of the closed chamber Keeling plot measurements was shown to potentially induce the proposed disequilibrium. Simulations with a soil $\mathrm{CO}_{2}$ transport model accounting for diffusion, advection and dissolution reproduced most $(9.5 \%$ ) of the observed disequilibrium effect $(11.2 \%$ ). In contrast, simulations excluding either dissolution or advection or both accounted for less than half of the observed disequilibrium effect. This strongly suggests that, besides diffusion, both dissolution and advection contributed significantly to the observed disequilibrium effect and, hence, that soil $\mathrm{CO}_{2}$ pools and species other than gaseous $\mathrm{CO}_{2}$ (e.g., dissolved bicarbonate) were involved. The disequilibrium effect strongly affected data interpretation in terms of ecosystem respiration, since its magnitude $(11.2 \%$ ) corresponded to $\sim 30 \%$ of the tracer signal (difference in $\delta^{13} \mathrm{C}_{\mathrm{atm}}$ between ambient $(-8.5 \%$ ) and labelling conditions $(-46.9 \%)$ ) in our experimental study. If interpreted in terms of tracer content of soil respiration, the disequilibrium effect would have been even larger. A similar phenomenon (disequilibrium or "abiotic" tracer flux) was noted by Subke et al. (2009) who used a diffusion model and a much stronger label $\left(\delta_{\mathrm{atm}} \sim 23000 \%\right.$ as compared to $-46.9 \%$ in our study).

The simulation of the tracer time series suggested that dissolution of $\mathrm{CO}_{2}$ in soil water significantly influenced the magnitude of the disequilibrium effect observed in the present experimental study. Dissolved $\mathrm{CO}_{2}$ represented a reservoir allowing storage of a large amount of label $\mathrm{CO}_{2}$ in the soil in addition to $\mathrm{CO}_{2}$ in soil air pores. Involvement of dissolved $\mathrm{CO}_{2}$ in soil $\mathrm{CO}_{2}$ transport processes delayed the equilibration between $\mathrm{CO}_{2}$ in soil air and the overlying atmosphere and slowed re-equilibration of $\delta^{13} \mathrm{C}_{\text {efflux }}$. Dissolved $\mathrm{CO}_{2}$ was modelled as part of soil $\mathrm{CO}_{2}$ transport assuming instantaneous exchange between gaseous and dissolved 

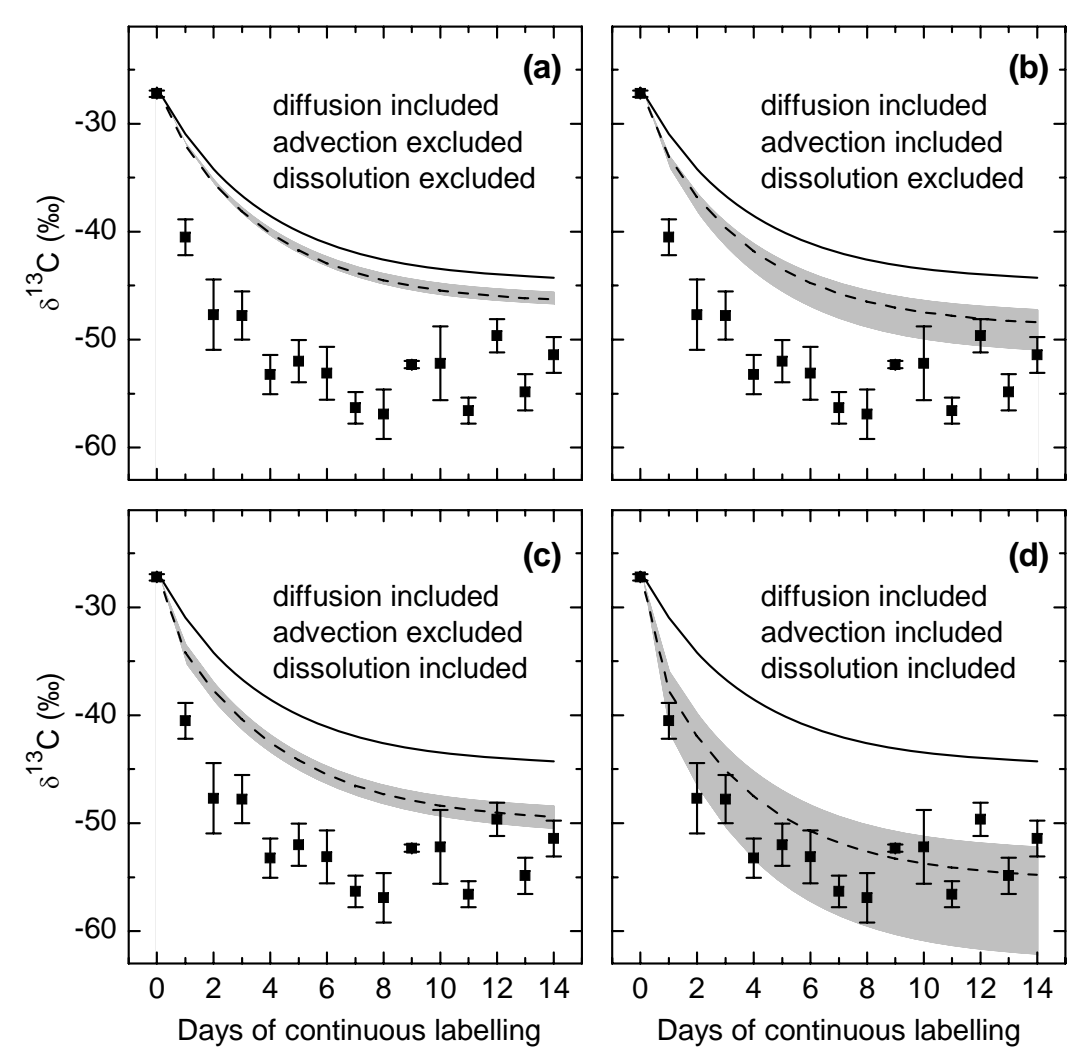

Fig. 6. The $\delta^{13} \mathrm{C}_{\mathrm{Rs}}$ estimated from open chamber measurements (solid lines), and $\delta^{13} \mathrm{C}_{\text {efflux }}$ derived from measured (dots; error bars: $\mathrm{SE}$ of replicate plots, $n=2-10$ ) and modelled (dashed lines) Keeling plot intercepts in closed chambers. Simulations exclude (a, b) or include (c, d) dissolution of $\mathrm{CO}_{2}$ in soil water, and exclude $(\mathbf{a}, \mathbf{c})$ or include $(\mathbf{b}, \mathbf{d})$ advection during daytime tracer application. The grey shaded areas indicate the sensitivity of modelled Keeling plot intercepts to variations of input parameters (see Table 1 for range).

phase. This assumption was valid if the gaseous-dissolved phase chemical equilibration was fast compared to the isotopic equilibration between soil air $\mathrm{CO}_{2}$ and overlying atmosphere. The latter occured within hours to days. Presumably, gaseous-dissolved phase equilibration was much faster, as it was probably catalysed by carbonic anhydrase. Carbonic anhydrase was previously found in soil inhabitating organisms such as bacteria (Kusian et al., 2002; Mitsuhashi et al., 2004) and fungi (Aguilera et al., 2005; Amoroso et al., 2005; Klengel et al., 2005; Mogensen et al., 2006), as well as in nonphotosynthetic plant organs and tissues (Raven and Newman, 1994), particularly roots (Viktor and Cramer, 2005) and growing root tips (Chang and Roberts, 1992). Furthermore, Seibt et al. (2006) and Wingate et al. (2008) provided evidence for the presence of carbonic anhydrase in the upper soil horizons, accelerating the hydration of bicarbonate by a factor of $80-1000$ (which corresponded to equilibration within less than $1 \mathrm{~s}$ ). Considering these timescales, participation of a major fraction of dissolved $\mathrm{CO}_{2}$ in soil gas transport is likely, even if isotopic equilibrium was not fully reached. However, Reardon et al. (1979) found that $\delta^{13} \mathrm{C}$ of $\mathrm{CO}_{2}$ species in groundwater was consistent with complete isotopic equilibration of $\mathrm{CO}_{2}$ in soil water with $\mathrm{CO}_{2}$ in soil gas. In agreement with the suggestion of Högberg et al. (2008), the present findings strongly suggest (at least partial) isotopic equilibration of label $\mathrm{CO}_{2}$ with $\mathrm{CO}_{2}$ species dissolved in soil water.

The capacity of the soil to store isotopically labelled $\mathrm{CO}_{2}$ is expected to be largest under alkaline conditions, as the amount of $\mathrm{CO}_{2}$ in the dissolved phase increases with $\mathrm{pH}$. This is consistent with the re-equilibration of $\delta^{13} \mathrm{C}_{\text {efflux }}$ following a change in $\delta^{13} \mathrm{C}_{\mathrm{atm}}$, since the simulated reequilibration time increases strongly with $\mathrm{pH}$ (Fig. 8). At low $\mathrm{pH}$ values (below $\sim 6$ ), the concentration of dissolved carbon species is dominated by $\mathrm{H}_{2} \mathrm{CO}_{3}(\mathrm{aq})$. The $\mathrm{H}_{2} \mathrm{CO}_{3}(\mathrm{aq})$ concentration is constant for a given temperature and $\mathrm{CO}_{2}$ concentration in the air, and approximately the same amount of carbon is dissolved as $\mathrm{H}_{2} \mathrm{CO}_{3}(\mathrm{aq})$ and in the gaseous phase as $\mathrm{CO}_{2}$, if volumes of water and air are equal (Bunsen coefficient, which is the ratio $c_{\mathrm{w}} / c_{\mathrm{a}}, \sim 1$ ). At $\mathrm{pH}$ values above $\sim 6, \mathrm{HCO}_{3}^{-}$dominates the dissolved carbon species. As the $\mathrm{HCO}_{3}^{-}$concentration increases exponentially with $\mathrm{pH}$, the $\mathrm{CO}_{2}$ storage capacity of soil water increases strongly with alkalinity. Under alkaline conditions a multiple of the amount of carbon in the gaseous phase $\left(\mathrm{CO}_{2}\right)$ is dissolved in an equal volume of water (Bunsen coefficient $\gg 1$ ). In the present 

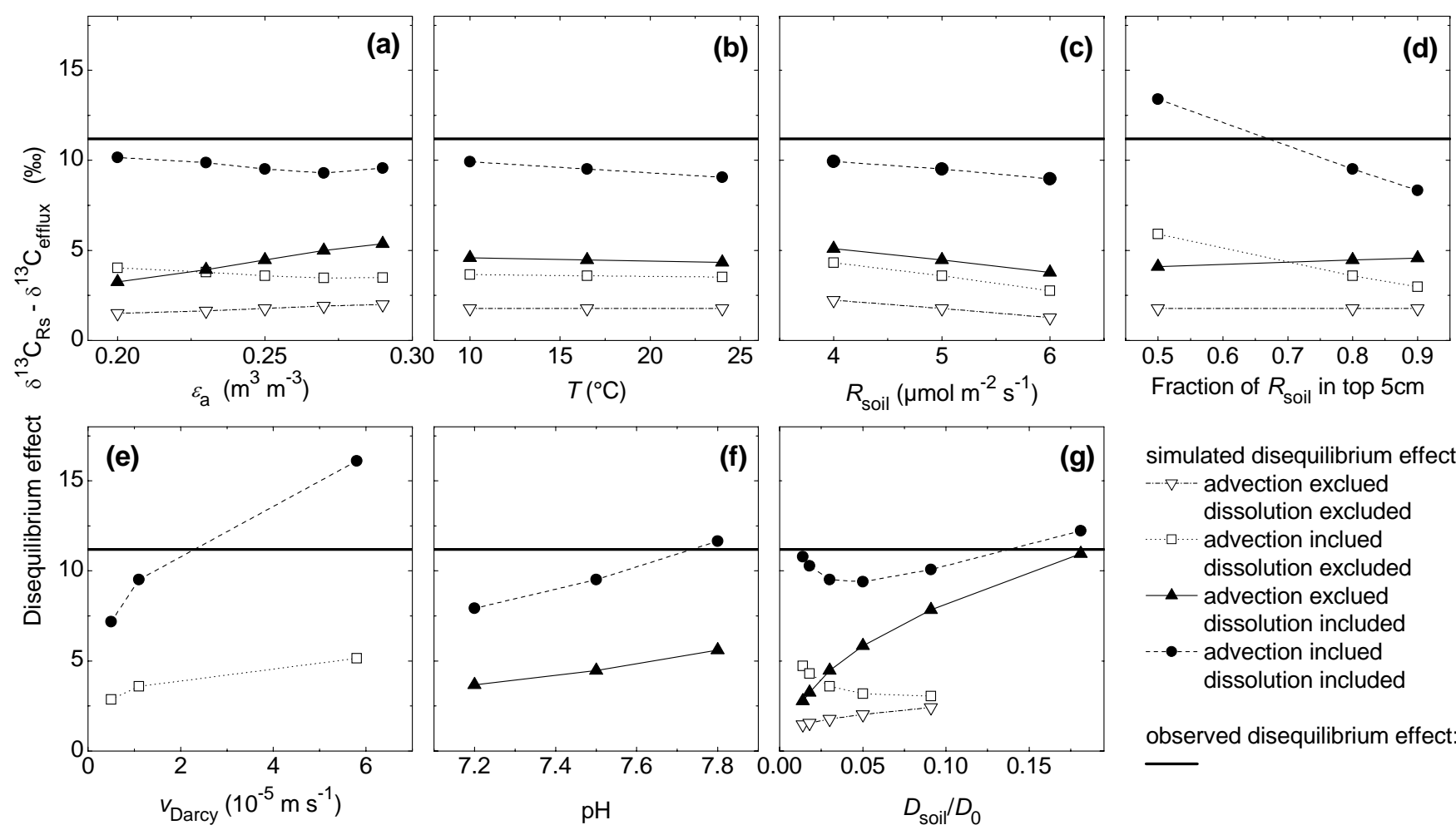

simulated disequilibrium effect:

$\cdots \cdots$ advection exclued dissolution excluded

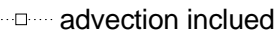
dissolution excluded

$\_$advection exclued dissolution included

--advection inclued dissolution included

observed disequilibrium effect:

Fig. 7. Sensitivity of simulated disequilibrium effect to variations in the model input parameters as shown in Table 1 . Disequilibrium effects are shown as means during the labelling period. Simulations exclude (open symbols) or include (closed symbols) dissolution, and exclude (triangles) or include (circles and squares) advection. The observed disequilibrium effect is indicated by the thick solid line. The investigated parameters include (a) air-filled porosity (which covaried with water-filled porosity according to Table 1), (b) soil temperature, (c) soil respiration rate, (d) depth distribution of soil respiration, (e) Darcy velocity, (f) $\mathrm{pH}$, and (g) the choice of a soil diffusivity model.

study $(\mathrm{pH}=7.5)$ the Bunsen coefficient was 12.4. In contrast, at the experimental site of Subke et al. (2009) the $\mathrm{pH}$ was low (4.5), indicating that dissolved $\mathrm{CO}_{2}$ played a much smaller role in that study than in our example.

Downward advection of soil air also affected our $\delta^{13} \mathrm{C}_{\mathrm{efflux}}$ measurements. Chamber headspace pressurization during daytime tracer application (Gamnitzer et al., 2009) presumably displaced soil air masses downwards (Lund et al., 1999), as the soil collars of the chambers restricted lateral movement. The $\delta^{13} \mathrm{C}_{\text {efflux }}$ measurements were conducted during nighttime and thus subsequent to the daytime phase of advective transport. Nevertheless, the simulations suggest that the measurements were influenced by the preceding pressurization.

Mechanisms which were not included in the simulation may have accounted for the residual disequilibrium effect of $1.7 \%$ o between modelled and observed $\delta^{13} \mathrm{C}_{\text {efflux }}$. These mechanisms included temporal changes of parameters (such as temperature, soil water content and respiration rate) during the course of the labelling experiment, diffusion in the dissolved phase, advection of soil water or incomplete isotopic equilibration between gaseous and dissolved $\mathrm{CO}_{2}$.

\subsection{Relevance to other experimental conditions}

Isotopic labelling signals of similar magnitude are frequently applied in Free-Air $\mathrm{CO}_{2}$ Enrichment (FACE) experiments, which are usually operated at $\delta^{13} \mathrm{C}$ of elevated $\mathrm{CO}_{2}$ between $-15 \%$ and $-20 \%$ (e.g., Nitschelm et al., 1997; Matamala et al., 2003; Asshoff et al., 2006; Keel et al., 2006; Pregitzer et al., 2006; Taneva et al., 2006). When FACE experiments are combined with measurements of $\delta^{13} \mathrm{C}_{\text {efflux }}$ (Torn et al., 2003; Søe et al., 2004; Pregitzer et al., 2006; Taneva et al., 2006; Taneva and Gonzalez-Meler, 2011) and fumigation with isotopically different $\mathrm{CO}_{2}$ is restricted to daytime (e.g., Lewin et al., 1994; Zanetti et al., 1996; Miglietta et al., 1997; Hendrey et al., 1999; Dickson et al., 2000; Edwards et al., 2001; Miglietta et al., 2001; Reich et al., 2001; Pepin and Körner, 2002; Talhelm et al., 2007), the measurements are potentially affected by disequilibrium effects as observed in the present study, if these measurements are performed shortly after the nighttime switch-off of the fumigation. Disequilibrium effects on $\delta^{13} \mathrm{C}_{\text {efflux }}$ are also expected in pulsechase experiments, where highly enriched ${ }^{13} \mathrm{CO}_{2}$ is applied (Subke et al., 2009, see Fig. 9 for estimates at our study site). However, the time course of disequilibrium effects must be considered, since the disequilibrium is largest immediately 


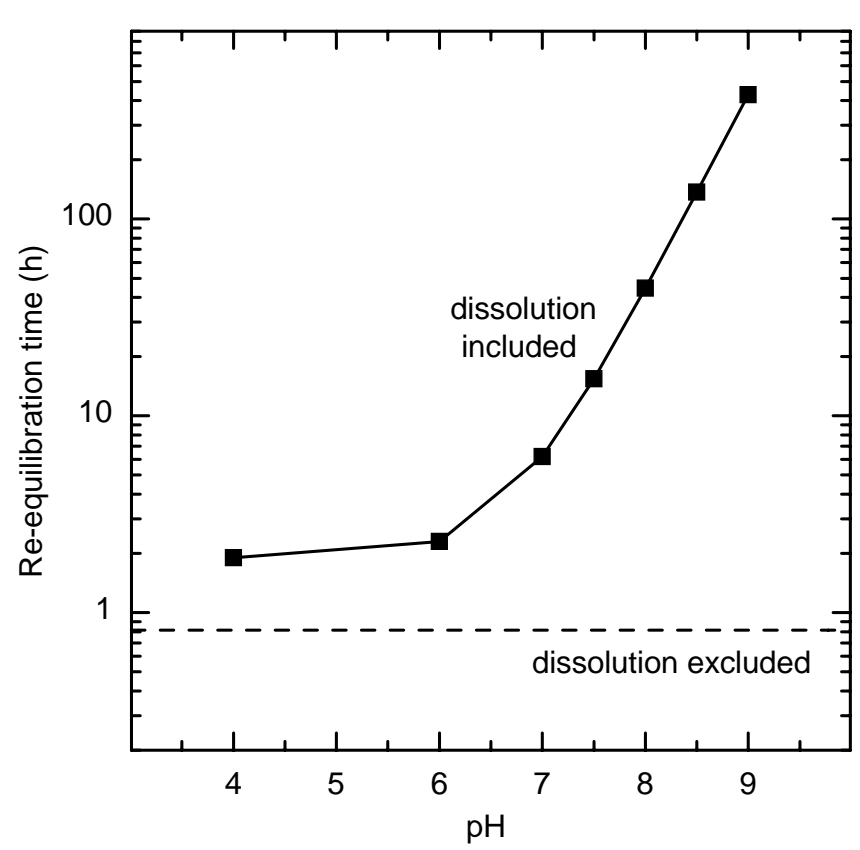

Fig. 8. Modelled re-equilibration time, the time interval between a step change in $\delta^{13} \mathrm{C}_{\mathrm{atm}}$ from labelling $(-46.9 \%$ ) to ambient $\left(-8.5 \%\right.$ o conditions and $\delta^{13} \mathrm{C}_{\text {efflux }}$ reaching $\delta^{13} \mathrm{C}_{\mathrm{Rs}}$ within $0.4 \%$ o (corresponding to $1 \%$ of the difference between ambient and labelled $\mathrm{CO}_{2}$ ). Simulations included dissolution for various $\mathrm{pH}$ values (closed squares) or excluded dissolution (dashed line).

after its initiation (the atmospheric change) and decreases with time (see Fig. 4). Thus, early initiation of sampling and short sampling duration will increase disequilibrium effects comprised in a chamber measurement. In our grassland experiment, the disequilibrium effect was relevant for hours to days. This was consistent with observations in a boreal forest ecosystem, where the disequilibrium ("abiotic") tracer flux was significant for $48 \mathrm{~h}$ (Subke et al., 2009).

In some instances chamber techniques have involved a lowering of the chamber headspace $\mathrm{CO}_{2}$ concentration at the onset of the measurements (Flanagan et al., 1996; Buchmann and Ehleringer, 1998; Ohlsson et al., 2005). This procedure alters not only the soil-atmosphere $\mathrm{CO}_{2}$ gradient but also the ${ }^{12} \mathrm{CO}_{2}$ and ${ }^{13} \mathrm{CO}_{2}$ gradients, and thus $\delta^{13} \mathrm{C}_{\mathrm{efflux}}$, as shown by Ohlsson et al. (2005). In a theoretical investigation considering $\mathrm{CO}_{2}$ in soil air, Nickerson and Risk (2009c) predicted a disequilibrium effect (deviation between $\delta^{13} \mathrm{C}_{\mathrm{Rs}}$ and $\delta^{13} \mathrm{C}_{\text {efflux }}$ observed with such chambers) of up to $15 \%$. This disequilibrium effect would be even larger when dissolution of $\mathrm{CO}_{2}$ in soil water occurred. This applies when the gaseous-dissolved phase chemical equilibration is fast compared to the isotopic equilibration between soil air $\mathrm{CO}_{2}$ and overlying atmosphere (such as in the presence of carbonic anhydrase in the soil). Natural variability in atmospheric $\mathrm{CO}_{2}$ would cause the same disequilibrium effect as a change of headspace $\mathrm{CO}_{2}$ inside the chambers. Diurnal cy-

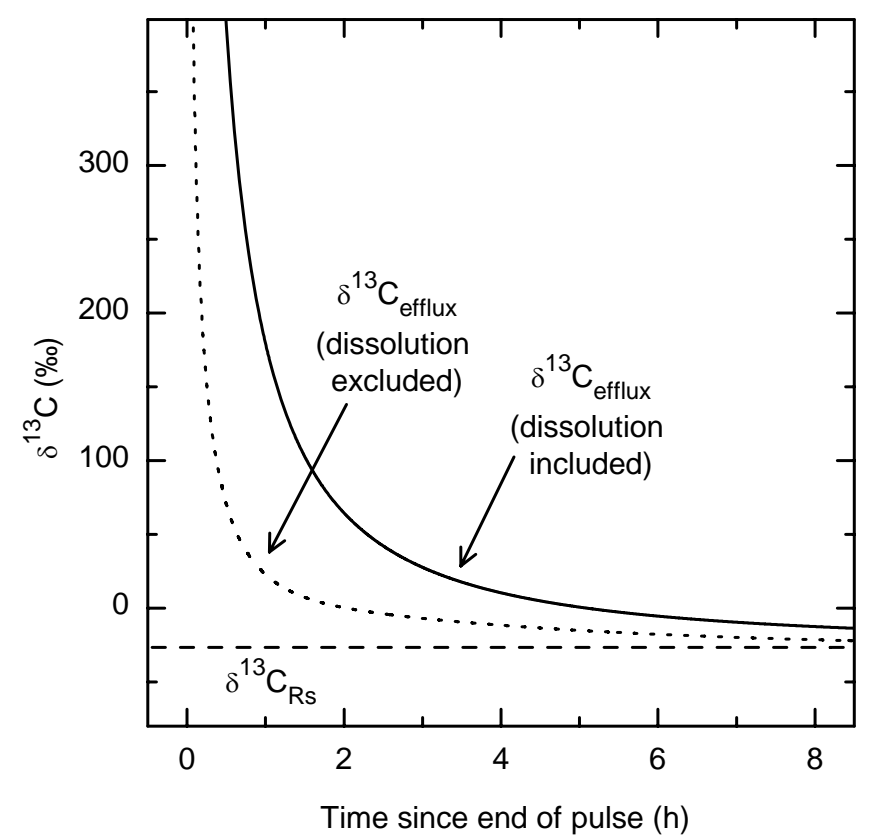

Fig. 9. Modelled $\delta^{13} \mathrm{C}_{\text {efflux }}$ following pulse labelling with highly enriched $\mathrm{CO}_{2}\left(20\right.$ atom $\left.\%{ }^{13} \mathrm{CO}_{2}\right)$ for $1 \mathrm{~h}$. Dissolution of $\mathrm{CO}_{2}$ in soil water was included (solid line) or excluded (dotted line) in the $\mathrm{CO}_{2}$ transport model. $\delta^{13} \mathrm{C}_{\mathrm{Rs}}$ was kept constant at $-26.7 \%$ (dashed line).

cles of $\delta^{13} \mathrm{C}_{\mathrm{atm}}$ can show amplitudes of $\sim 10 \%$ (e.g., Schnyder et al., 2004). Using a diffusion-based model Nickerson and Risk (2009a) predicted a disequilibrium effect within $0.05 \%$ resulting from daytime-nighttime changes of both atmospheric $\mathrm{CO}_{2}$ concentration and $\delta^{13} \mathrm{C}$. However, inclusion of the dissolution mechanism would likely multiply this disequilibrium effect.

Acknowledgements. The members of the Lehrstuhl für Grünlandlehre are thanked for valuable discussions, in particular Rudi Schäufele, Christoph Lehmeier, Inga Schleip and Karl Auerswald. Richard Wenzel provided excellent technical assistance. Furthermore, we want to thank the two ananymous reviewers for their detailed suggestions which helped to improve the manuscript. This work was partially supported by the Deutsche Forschungsgemeinschaft (SFB 607). ABM is grateful for generous support from the A. Herbert and Marian W. Gold Scholarship at the University of Utah.

Edited by: M. Bahn

\section{References}

Aguilera, J., Van Dijken, J. P., De Winde, J. H., and Pronk, J. T.: Carbonic anhydrase (NCE103p): an essential biosynthetic enzyme for growth of Saccharomyces cerevisiae at atmospheric carbon dioxide pressure, Biochem. J., 391, 311-316, 2005.

Amoroso, G., Morell-Avrahov, L., Müller, D., Klug, K., and Sültemeyer, D.: The gene NCE103 (YNL036w) from Saccha- 
romyces cerevisiae encodes a functional carbonic anhydrase and its transcription is regulated by the concentration of inorganic carbon in the medium, Mol. Microbiol., 56, 549-558, 2005.

Amundson, R. G. and Davidson, E. A.: Carbon-dioxide and nitrogenous gases in the soil atmosphere, J. Geochem. Exploration, 38, 13-41, 1990.

Amundson, R., Stern, L., Baisden, T., and Wang, Y.: The isotopic composition of soil and soil-respired $\mathrm{CO}_{2}$, Geoderma, 82, 83114, 1998.

Asshoff, R., Zotz, G., and Körner, C.: Growth and phenology of mature temperate forest trees in elevated $\mathrm{CO}_{2}$, Global Change Biol., 12, 848-861, 2006.

Bahn, M., Schmitt, M., Siegwolf, R., Richter, A., and Brüggemann, N.: Does photosynthesis affect grassland soil-respired $\mathrm{CO}_{2}$ and its carbon isotope composition on a diurnal timescale?, New Phytologist, 182, 451-460, 2009.

Ball, B. C., Campbell, D. J., Douglas, J. T., Henshall, J. K., and O'Sullivan, M. F.: Soil structural quality, compaction and land management, Eur. J. Soil Sci., 48, 593-601, 1997.

Bowling, D. R., Massman, W. J., Schaeffer, S. M., Burns, S. P., Monson, R. K., and Williams, M. W.: Biological and physical influences on the carbon isotope content of $\mathrm{CO}_{2}$ in a subalpine forest snowpack, Niwot Ridge, Colorado, Biogeochemistry, 95, 37-59, 2009.

Buchmann, N. and Ehleringer, J. R.: $\mathrm{CO}_{2}$ concentration profiles, and carbon and oxygen isotopes in $\mathrm{C} 3$ and $\mathrm{C} 4$ crop canopies, Agr. Forest Meteorol., 89, 45-58, 1998.

Camarda, M., Gregorio, S. D., Favara, R., and Gurrieri, S.: Evaluation of carbon isotope fractionation of soil $\mathrm{CO}_{2}$ under an advective-diffusive regimen: a tool for computing the isotopic composition of unfractionated deep source, Geochim. Cosmochim. Ac., 71, 3016-3027, 2007.

Campbell, G. S. and Norman, J. M.: An Introduction to Environmental Biophysics, Springer, New York, 1998.

Carbone, M. S. and Trumbore, S. E.: Contribution of new photosynthetic assimilates to respiration by perennial grasses and shrubs: residence times and allocation patterns, New Phytol., 176, 124135, 2007.

Carbone, M. S., Czimczik, C. I., McDuffee, K. E., and Trumbore, S. E.: Allocation and residence time of photosynthetic products in a boreal forest using a low-level ${ }^{14} \mathrm{C}$ pulse-chase labeling technique, Global Change Biol., 13, 466-477, 2007.

Cerling, T. E.: The stable isotopic composition of modern soil carbonate and its relationship to climate, Earth Planet. Sci. Lett., 71, 229-240, 1984.

Cerling, T. E., Solomon, D. K., Quade, J., and Bowman, J. R.: On the isotopic composition of carbon in soil carbon-dioxide, Geochim. Cosmochim. Ac., 55, 3403-3405, 1991.

Chang, K. J. and Roberts, J. K. M.: Quantitation of rates of transport, metabolic fluxes, and cytoplasmic levels of inorganic carbon in maize root-tips during $\mathrm{K}^{+}$ion uptake, Plant Physiol., 99, 291-297, 1992.

Davidson, E. A., Savage, K., Verchot, L. V., and Navarro, R.: Minimizing artifacts and biases in chamber-based measurements of soil respiration, Agr. Forest Meteorol., 113, 21-37, 2002.

Dickson, R. E., Lewin, K. F., Isebrands, J. G., Coleman, M. D., Heilmann, W. E., Riemenschneider, D. E., Sober, J., Host, G. E., Hendrey, G. R., Pregitzer, K. S., and Karnosky, D. F.: Forest atmosphere carbon transfer storage (FACTS-II) - the aspen free- air $\mathrm{CO}_{2}$ and $\mathrm{O}_{3}$ enrichment (FACE) project: an overview, Tech. Rep. NC-214, USDA Forest Service, North Central Experiment Station, St. Paul, MN, USA, 2000.

Dudziak, A. and Halas, S.: Diurnal cycle of carbon isotope ratio in soil $\mathrm{CO}_{2}$ in various ecosystems, Plant Soil, 183, 291-299, 1996.

Edwards, G. R., Clark, H., and Newton, P. C. D.: The effects of elevated $\mathrm{CO}_{2}$ on seed production and seedling recruitment in a sheep-grazed pasture, Oecologia, 127, 383-394, 2001.

Ekblad, A., Bostrom, B., Holm, A., and Comstedt, D.: Forest soil respiration rate and $\delta^{13} \mathrm{C}$ is regulated by recent above ground weather conditions, Oecologia, 143, 136-142, 2005.

Epron, D., Ngao, J., Dannoura, M., Bakker, M. R., Zeller, B., Bazot, S., Bosc, A., Plain, C., Lata, J. C., Priault, P., Barthes, L., and Loustau, D.: Seasonal variations of belowground carbon transfer assessed by in situ ${ }^{13} \mathrm{CO}_{2}$ pulse labelling of trees, Biogeosciences, 8, 1153-1168, doi:10.5194/bg-8-1153-2011, 2011.

Fang, C. and Moncrieff, J. B.: An open-top chamber for measuring soil respiration and the influence of pressure difference on $\mathrm{CO}_{2}$ efflux measurement, Funct. Ecol., 12, 319-325, 1998.

Fang, C. and Moncrieff, J. B.: A model for soil $\mathrm{CO}_{2}$ production and transport, 1. Model development, Agr. Forest Meteorol., 95, 225-236, 1999.

Fish, A. N. and Koppi, A. J.: The use of a simple field air permeameter as a rapid indicator of functional soil pore-space, Geoderma, 63, 255-264, 1994.

Flanagan, L. B., Brooks, J. R., Varney, G. T., Berry, S. C., and Ehleringer, J. R.: Carbon isotope discrimination during photosynthesis and the isotope ratio of respired $\mathrm{CO}_{2}$ in boreal forest ecosystems, Global Biogeochem. Cy., 10, 629-640, 1996.

Flessa, H. and Fischer, W.: Plant-induced changes in the redox potentials of rice rhizospheres, Plant Soil, 143, 55-60, 1992.

Fuller, E. N., Schettle, P. D., and Giddings, J. C.: A new method for prediction of binary gas-phase diffusion coefficients, Ind. Eng. Chem., 58, 19-27, 1966.

Gamnitzer, U., Schäufele, R., and Schnyder, H.: Observing ${ }^{13} \mathrm{C}$ labelling kinetics in $\mathrm{CO}_{2}$ respired by a temperate grassland ecosystem, New Phytol., 184, 376-386, 2009.

Gavrichkova, O., Proietti, S., Moscatello, S., Portarena, S., Battistelli, A., Matteucci, G., and Brugnoli, E.: Short-term natural $\delta^{13} \mathrm{C}$ variations in pools and fluxes in a beech forest: the transfer of isotopic signal from recent photosynthates to soil respired $\mathrm{CO}_{2}$, Biogeosciences Discuss., 8, 2403-2437, doi:10.5194/bgd8-2403-2011, 2011.

Hendrey, G. R., Ellsworth, D. S., Lewin, K. F., and Nagy, J.: A freeair enrichment system for exposing tall forest vegetation to elevated atmospheric $\mathrm{CO}_{2}$, Global Change Biol., 5, 293-309, 1999.

Högberg, P., Högberg, M. N., Göttlicher, S. G., Betson, N. R., Keel, S. G., Metcalfe, D. B., Campbell, C., Schindlbacher, A., Hurry, V., Lundmark, T., Linder, S., and Nasholm, T.: High temporal resolution tracing of photosynthate carbon from the tree canopy to forest soil microorganisms, New Phytol., 177, 220 228, 2008.

Horwath, W. R., Pregitzer, K. S., and Paul, E. A.: ${ }^{14} \mathrm{C}$ allocation in tree soil systems, Tree Physiol., 14, 1163-1176, 1994.

Kammer, A., Tuzson, B., Emmenegger, L., Knohl, A., Mohn, J., and Hagedorn, F.: Application of a quantum cascade laser-based spectrometer in a closed chamber system for real-time $\delta^{13} \mathrm{C}$ and $\delta^{18} \mathrm{O}$ measurements of soil-respired $\mathrm{CO}_{2}$, Agr. Forest Meteorol., $151,39-48,2011$. 
Kanemasu, E. T., Powers, W. L., and Sij, J. W.: Field chamber measurements of $\mathrm{CO}_{2}$ flux from soil surface, Soil Sci., 118, 233-237, 1974.

Kayler, Z. E., Sulzman, E. W., Marshall, J. D., Mix, A., Rugh, W. D., and Bond, B. J.: A laboratory comparison of two methods used to estimate the isotopic composition of soil $\delta^{13} \mathrm{CO}_{2}$ efflux at steady state, Rapid Commun. Mass Spectrom., 22, 2533-2538, 2008.

Kayler, Z. E., Ganio, L., Hauck, M., Pypker, T. G., Sulzman, E. W., Mix, A. C., and Bond, B. J.: Bias and uncertainty of $\delta^{13} \mathrm{CO}_{2}$ isotopic mixing models, Oecologia, 163, 227-234, 2010a.

Kayler, Z. E., Sulzman, E. W., Rugh, W. D., Mix, A. C., and Bond, B. J.: Characterizing the impact of diffusive and advective soil gas transport on the measurement and interpretation of the isotopic signal of soil respiration, Soil Biol. Biochem., 42, 435-444, $2010 b$.

Keel, S. G., Siegwolf, R. T. W., and Körner, C.: Canopy $\mathrm{CO}_{2}$ enrichment permits tracing the fate of recently assimilated carbon in a mature deciduous forest, New Phytol., 172, 319-329, 2006.

Keeling, C. D.: The concentration and isotopic abundances of atmospheric carbon dioxide in rural areas, Geochim. Cosmochim. Ac., 13, 322-334, 1958 .

Klapp, E.: Wiesen und Weiden, Paul Parey, Berlin, Germany, 1971. Klengel, T., Liang, W. J., Chaloupka, J., Ruoff, C., Schröppel, K., Naglik, J. R., Eckert, S. E., Mogensen, E. G., Haynes, K., Tuite, M. F., Levin, L. R., Buck, J., and Mühlschlegel, F. A.: Fungal adenylyl cyclase integrates $\mathrm{CO}_{2}$ sensing with cAMP signaling and virulence, Curr. Biol., 15, 2021-2026, 2005.

Koehler, B., Zehe, E., Corre, M. D., and Veldkamp, E.: An inverse analysis reveals limitations of the soil- $\mathrm{CO}_{2}$ profile method to calculate $\mathrm{CO}_{2}$ production and efflux for well-structured soils, Biogeosciences, 7, 2311-2325, doi:10.5194/bg-7-2311-2010, 2010.

Kusian, B., Sültemeyer, D., and Bowien, B.: Carbonic anhydrase is essential for growth of Ralstonia eutropha at ambient $\mathrm{CO}_{2}$ concentrations, J. Bacteriol., 184, 5018-5026, 2002.

Leake, J. R., Ostle, N. J., Rangel-Castro, J. I., and Johnson, D.: Carbon fluxes from plants through soil organisms determined by field ${ }^{13} \mathrm{CO}_{2}$ pulse-labelling in an upland grassland, Appl. Soil Ecol., 33, 152-175, 2006.

Lewin, K. F., Hendrey, G. R., Nagy, J., and LaMorte, R. L.: Design and application of a free-air carbon-dioxide enrichment facility, Agr. Forest Meteorol., 70, 15-29, 1994.

Livingston, G. P. and Hutchinson, G. L.: Enclosure-based measurement of trace gas exchange: applications and sources of error, in: Biogenic Trace Gases: Measuring Emissions from Soil and Water, edited by: Matson, P. A. and Harriss, R. C., Blackwell Science, Oxford, UK, 14-51, 1995.

Lund, C. P., Riley, W. J., Pierce, L. L., and Field, C. B.: The effects of chamber pressurization on soil-surface $\mathrm{CO}_{2}$ flux and the implications for NEE measurements under elevated $\mathrm{CO}_{2}$, Global Change Biol., 5, 269-281, 1999.

Maseyk, K., Wingate, L., Seibt, U., Ghashghaie, J., Bathellier, C., Almeida, P., de Vale, R. L., Pereira, J. S., Yakir, D., and Mencuccini, M.: Biotic and abiotic factors affecting the $\delta^{13} \mathrm{C}$ of soil respired $\mathrm{CO}_{2}$ in a Mediterranean oak woodland, Isotopes in Environmental and Health Studies, 45, 343-359, 2009.

Matamala, R., Gonzalez-Meler, M. A., Jastrow, J. D., Norby, R. J., and Schlesinger, W. H.: Impacts of fine root turnover on forest NPP and soil C sequestration potential, Science, 302, 1385-
1387, 2003.

McDowell, N. G., Bowling, D. R., Bond, B. J., Irvine, J., Law, B. E., Anthoni, P., and Ehleringer, J. R.: Response of the carbon isotopic content of ecosystem, leaf, and soil respiration to meteorological and physiological driving factors in a Pinus ponderosa ecosystem, Global Biogeochem. Cy., 18, GB1013, doi:10.1029/2003GB002049, 2004.

Miglietta, F., Lanini, M., Bindi, M., and Magliulo, V.: Free air $\mathrm{CO}_{2}$ enrichment of potato (Solanum tuberosum L.): design and performance of the $\mathrm{CO}_{2}$-fumigation system, Global Change Biol., 3, 417-427, 1997.

Miglietta, F., Peressotti, A., Vaccari, F. P., Zaldei, A., deAngelis, P., and Scarascia-Mugnozza, G.: Free-air $\mathrm{CO}_{2}$ enrichment (FACE) of a poplar plantation: the POPFACE fumigation system, New Phytol., 150, 465-476, 2001.

Millard, P., Midwood, A. J., Hunt, J. E., Whitehead, D., and Boutton, T. W.: Partitioning soil surface $\mathrm{CO}_{2}$ efflux into autotrophic and heterotrophic components, using natural gradients in soil $\delta^{13} \mathrm{C}$ in an undisturbed savannah soil, Soil Biol. Biochem., 40, 1575-1582, 2008.

Millington, R. J.: Gas diffusion in porous media, Science, 130, 100102, 1959.

Millington, R. J. and Quirk, J. P.: Transport in Porous Media, in: Trans. 7th Int. Congr. Soil Sci., Vol. 1, edited by: Van Beren, F. A., Elsevier, Amsterdam, The Netherlands, 97-106, 1960.

Milne, R. M. and Haynes, R. J.: Comparative effects of annual and permanent dairy pastures on soil physical properties in the Tsitsikamma region of South Africa, Soil Use Manage., 20, 81-88, 2004.

Mitsuhashi, S., Ohnishi, J., Hayashi, M., and Ikeda, M.: A gene homologous to $\beta$-type carbonic anhydrase is essential for the growth of Corynebacterium glutamicum under atmospheric conditions, Appl. Microbiol. Biotechnol., 63, 592-601, 2004.

Mogensen, E. G., Janbon, G., Chaloupka, J., Steegborn, C., Fu, M. S., Moyrand, F., Klengel, T., Pearson, D. S., Geeves, M. A., Buck, J., Levin, L. R., and Mühlschlegel, F. A.: Cryptococcus neoformans senses $\mathrm{CO}_{2}$ through the carbonic anhydrase Can2 and the adenylyl cyclase Cac1, Eukaryot. Cell, 5, 103-111, 2006.

Moldrup, P., Olesen, T., Rolston, D. E., and Yamaguchi, T.: Modeling diffusion and reaction in soils: VII. Predicting gas and ion diffusivity in undisturbed and sieved soils, Soil Sci., 162, 632640, 1997.

Moldrup, P., Olesen, T., Yamaguchi, T., Schjønning, P., and Rolston, D. E.: Modeling diffusion and reaction in soils: IX. The Buckingham-Burdine-Campbell equation for gas diffusivity in undisturbed soil, Soil Sci., 164, 542-551, 1999.

Moldrup, P., Olesen, T., Schjonning, P., Yamaguchi, T., and Rolston, D. E.: Predicting the gas diffusion coefficient in undisturbed soil from soil water characteristics, Soil Sci. Society America J., 64, 94-100, 2000.

Moldrup, P., Olesen, T., Yoshikawa, S., Komatsu, T., and Rolston, D. E.: Three-porosity model for predicting the gas diffusion coefficient in undisturbed soil, Soil Sci. Society America J., 68, 750-759, 2004.

Mook, W. G.: Environmental isotopes in the hydrological cycle. Principles and applications, Vol. I, Introduction: Theory, methods, review, UNESCO, Technical Documents in Hydrology, 39, Paris, France, 2000. 
Mook, W. G., Bommerson, J. C., and Staverman, W. H.: Carbon isotope fractionation between dissolved bicarbonate and gaseous carbon dioxide, Earth Planet. Sc. Lett., 22, 169-176, 1974.

Mortazavi, B., Chanton, J. P., Prater, J. L., Oishi, A. C., Oren, R., and Katul, G.: Temporal variability in ${ }^{13} \mathrm{C}$ of respired $\mathrm{CO}_{2}$ in a pine and a hardwood forest subject to similar climatic conditions, Oecologia, 142, 57-69, 2005.

Moyes, A. B., Gaines, S. J., Siegwolf, R. T. W., and Bowling, D. R.: Diffusive fractionation complicates isotopic partitioning of autotrophic and heterotrophic sources of soil respiration, Plant Cell Environ., 33, 1804-1819, 2010.

Munkholm, L. J., Schjønning, P., and Rüegg, K.: Mitigation of subsoil recompaction by light traffic and on-land ploughing, 1 . Soil response, Soil Till. Res., 80, 149-158, 2005.

Nickerson, N. and Risk, D.: Physical controls on the isotopic composition of soil-respired $\mathrm{CO}_{2}$, J. Geophys. Res., 114, G01013, doi:10.1029/2008JG000766, 2009a.

Nickerson, N. and Risk, D.: Keeling plots are non-linear in nonsteady state diffusive environments, Geophys. Res. Lett., 36, L08401, doi:10.1029/2008GL036945, 2009b.

Nickerson, N. and Risk, D.: A numerical evaluation of chamber methodologies used in measuring the $\delta^{13} \mathrm{C}$ of soil respiration, Rapid Commun. Mass Sp., 23, 2802-2810, 2009c.

Nitschelm, J. J., Lüscher, A., Hartwig, U. A., and Van Kessel, C.: Using stable isotopes to determine soil carbon input differences under ambient and elevated atmospheric $\mathrm{CO}_{2}$ conditions, Global Change Biol., 3, 411-416, 1997.

Ohlsson, K. E. A.: Reduction of bias in static closed chamber measurement of $\delta^{13} \mathrm{C}$ in soil $\mathrm{CO}_{2}$ efflux, Rapid Commun. Mass Sp., 24, 180-184, 2010.

Ohlsson, K. E. A.: Theoretical model of the abiotic component of soil ${ }^{13} \mathrm{CO}_{2}$ tracer efflux in ${ }^{13} \mathrm{C}$ pulse-labeling experiments on plant-soil systems, Soil Biol. Biochem., 43, 675-681, 2011.

Ohlsson, K. E. A., Bhupinderpal-Singh, Holm, S., Nordgren, A., Lövdahl, L., and Högberg, P.: Uncertainties in static closed chamber measurements of the carbon isotopic ratio of soilrespired $\mathrm{CO}_{2}$, Soil Biol. Biochem., 37, 2273-2276, 2005.

Ostle, N., Ineson, P., Benham, D., and Sleep, D.: Carbon assimilation and turnover in grassland vegetation using an in-situ ${ }^{13} \mathrm{CO}_{2}$ pulse labelling system, Rapid Commun. Mass Sp., 14, 13451350, 2000.

Pataki, D. E., Ehleringer, J. R., Flanagan, L. B., Yakir, D., Bowling, D. R., Still, C. J., Buchmann, N., Kaplan, J. O., and Berry, J. A.: The application and interpretation of Keeling plots in terrestrial carbon cycle research, Global Biogeochem. Cy., 17, 1022, doi:10.1029/2001GB001850, 2003.

Pepin, S. and Körner, C.: Web-FACE: A new canopy free-air $\mathrm{CO}_{2}$ enrichment system for tall trees in mature forests, Oecologia, 133, 1-9, 2002.

Phillips, C. L., Nickerson, N., Risk, D., Kayler, Z. E., Andersen, C., Mix, A., and Bond, B. J.: Soil moisture effects on the carbon isotope composition of soil respiration, Rapid Commun. Mass Sp., 24, 1271-1280, 2010.

Pregitzer, K., Loya, W., Kubiske, M., and Zak, D.: Soil respiration in northern forests exposed to elevated atmospheric carbon dioxide and ozone, Oecologia, 148, 503-516, 2006.

Pumpanen, J., Kolari, P., Ilvesniemi, H., Minkkinen, K., Vesala, T., Niinisto, S., Lohila, A., Larmola, T., Morero, M., Pihlatie, M., Janssens, I., Yuste, J. C., Grunzweig, J. M., Reth, S., Subke, J. A.,
Savage, K., Kutsch, W., Ostreng, G., Ziegler, W., Anthoni, P., Lindroth, A., and Hari, P.: Comparison of different chamber techniques for measuring soil $\mathrm{CO}_{2}$ efflux, Agr. Forest Meteorol., 123, 159-176, 2004.

Raven, J. A. and Newman, J. R.: Requirement for carbonicanhydrase activity in processes other than photosynthetic inorganic carbon assimilation, Plant Cell Environ., 17, 123-130, 1994.

Reardon, E. J., Allison, G. B., and Fritz, P.: Seasonal chemical and isotopic variations of soil $\mathrm{CO}_{2}$ at Trout Creek, Ontario, J. Hydrol., 43, 355-371, 1979.

Reich, P. B., Tilman, D., Craine, J., Ellsworth, D., Tjoelker, M. G., Knops, J., Wedin, D., Naeem, S., Bahauddin, D., Goth, J., Bengtson, W., and Lee, T. D.: Do species and functional groups differ in acquisition and use of $\mathrm{C}, \mathrm{N}$ and water under varying atmospheric $\mathrm{CO}_{2}$ and $\mathrm{N}$ availability regimes? A field test with 16 grassland species, New Phytol., 150, 435-448, 2001.

Revsbech, N. P., Pedersen, O., Reichardt, W., and Briones, A.: Microsensor analysis of oxygen and ph in the rice rhizosphere under field and laboratory conditions, Biology and Fertility of Soils, 29, 379-385, 1999.

Salmon, Y., Buchmann, N., and Barnard, R. L.: Response of $\delta^{13} \mathrm{C}$ in plant and soil respiration to a water pulse, Biogeosciences Discuss., 8, 4493-4527, doi:10.5194/bgd-8-4493-2011, 2011.

Schjønning, P., Munkholm, L. J., Elmholt, S., and Olesen, J. E.: Organic matter and soil tilth in arable farming: management makes a difference within 5-6 years, Agr. Ecosyst. Environ., 122, 157172, 2007.

Schnyder, H., Schäufele, R., and Wenzel, R.: Mobile, outdoor continuous-flow isotope-ratio mass spectrometer system for automated high-frequency ${ }^{13} \mathrm{C}$ - and ${ }^{18} \mathrm{O}-\mathrm{CO}_{2}$ analysis for Keeling plot applications, Rapid Commun. Mass Sp., 18, 3068-3074, 2004.

Schnyder, H., Schwertl, M., Auerswald, K., and Schäufele, R.: Hair of grazing cattle provides an integrated measure of the effects of site conditions and inter-annual weather variability on $\delta^{13} \mathrm{C}$ of temperate humid grassland, Global Change Biol., 12, 1-15, 2006.

Seibt, U., Wingate, L., Lloyd, J., and Berry, J. A.: Diurnally variable $\delta^{18} \mathrm{O}$ signatures of soil $\mathrm{CO}_{2}$ fluxes indicate carbonic anhydrase activity in a forest soil, J. Geophys. Res., 111, G04005, doi:10.1029/2006JG000177, 2006.

Šimůnek, J. and Suarez, D. L.: Modeling of carbon-dioxide transport and production in soil, 1. Model development, Water Resour. Res., 29, 487-497, 1993.

Søe, A. R. B., Giesemann, A., Anderson, T. H., Weigel, H. J., and Buchmann, N.: Soil respiration under elevated $\mathrm{CO}_{2}$ and its partitioning into recently assimilated and older carbon sources, Plant Soil, 262, 85-94, 2004.

Staddon, P. L., Ostle, N., Dawson, L. A., and Fitter, A. H.: The speed of soil carbon throughput in an upland grassland is increased by liming, J. Exp. Bot., 54, 1461-1469, 2003.

Stumm, W. and Morgan, J. A.: Aquatic Chemistry: Chemical Equilibria and Rates in Natural Waters, John Wiley \& Sons, New York, USA, 1996.

Subke, J. A., Vallack, H. W., Magnusson, T., Keel, S. G., Metcalfe, D. B., Högberg, P., and Ineson, P.: Short-term dynamics of abiotic and biotic soil ${ }^{13} \mathrm{CO}_{2}$ effluxes after in-situ ${ }^{13} \mathrm{CO}_{2}$ pulse labelling of a boreal pine forest, New Phytol., 183, 349-357, 
2009.

Talhelm, A. F., Qadir, S. A., Powers, M. D., Bradley, K. L., Friend, A. L., and Pregitzer, K. S.: ${ }^{13} \mathrm{C}$ labeling of plant assimilates using a simple canopy-scale open air system, Plant Soil, 296, 227-234, 2007.

Taneva, L. and Gonzalez-Meler, M. A.: Distinct patterns in the diurnal and seasonal variability in four components of soil respiration in a temperate forest under free-air $\mathrm{CO}_{2}$ enrichment, Biogeosciences Discuss., 8, 2875-2911, doi:10.5194/bgd-8-2875-2011, 2011.

Taneva, L., Pippen, J. S., Schlesinger, W. H., and GonzalezMeler, M. A.: The turnover of carbon pools contributing to soil $\mathrm{CO}_{2}$ and soil respiration in a temperate forest exposed to elevated $\mathrm{CO}_{2}$ concentration, Global Change Biol., 12, 983-994, 2006.

Torn, M. S., Davis, S., Bird, J. A., Shaw, M. R., and Conrad, M. E.: Automated analysis of ${ }^{13} \mathrm{C}^{12} \mathrm{C}$ ratios in $\mathrm{CO}_{2}$ and dissolved inorganic carbon for ecological and environmental applications, Rapid Commun. Mass Sp., 17, 2675-2682, 2003.

Viktor, A. and Cramer, M. D.: The influence of root assimilated inorganic carbon on nitrogen acquisition/assimilation and carbon partitioning, New Phytol., 165, 157-169, 2005.

Vogel, J. C., Grootes, P. M., and Mook, W. G.: Isotopic fractionation between gaseous and dissolved carbon dioxide, Z. Phys., 230, 225-238, 1970.
Werner, C. and Gessler, A.: Diel variations in the carbon isotope composition of respired $\mathrm{CO}_{2}$ and associated carbon sources: a review of dynamics and mechanisms, Biogeosciences Discuss., 8, 2183-2233, doi:10.5194/bgd-8-2183-2011, 2011.

Wingate, L., Seibt, U., Maseyk, K., Ogee, J., Almeida, P., Yakir, D., Pereira, J. S., and Mencuccini, M.: Evaporation and carbonic anhydrase activity recorded in oxygen isotope signatures of net $\mathrm{CO}_{2}$ fluxes from a mediterranean soil, Global Change Biol., 14, 2178-2193, 2008.

Wood, B. D., Keller, C. K., and Johnstone, D. L.: Insitu measurement of microbial activity and controls on microbial $\mathrm{CO}_{2}$ production in the unsaturated zone, Water Resour. Res., 29, 647659, 1993.

Zanetti, S., Hartwig, U. A., Lüscher, A., Hebeisen, T., Frehner, M., Fischer, B. U., Hendrey, G. R., Blum, H., and Nösberger, J.: Stimulation of symbiotic $\mathrm{N}_{2}$ fixation in Trifolium repens $L$. under elevated atmospheric $p \mathrm{CO}_{2}$ in a grassland ecosystem, Plant Physiol., 112, 575-583, 1996.

Zobitz, J. M., Keener, J. P., Schnyder, H., and Bowling, D. R.: Sensitivity analysis and quantification of uncertainty for isotopic mixing relationships in carbon cycle research, Agric. For. Meteorol., 136, 56-75, 2006. 